\title{
SOIL EROSION SUSCEPTIBILITY MAPPING OF IMO RIVER BASIN USING MODIFIED GEOMORPHOMETRIC PRIORITISATION METHOD
}

\author{
Peter C. Nhilo ๑ , Caleb O. Ogbeta ๑ , Olagoke E. Daramola $\odot$, \\ Chukwuma J. Okolie $\bullet$, Michael J. Orji @ \\ Department of Surveying and Geoinformatics, University of Lagos, Lagos, Nigeria
}

Manuscript received: March 24, 2021

Revised version: August 27, 2021

\begin{abstract}
Nwilo P.C., Ogbeta C.O., Daramola O.E., Okolie C.J., Orji M.J., 2021. Soil erosion susceptibility mapping of Imo River Basin using modified geomorphometric prioritisation method. Quaestiones Geographicae 40(3), Bogucki Wydawnictwo Naukowe, Poznań, pp. 143-162. 7 tables, 7 figs.

ABSTRACT: Gullies and other forms of erosion have been the greatest environmental problem and catastrophe in most high- and low-income countries. The challenge posed by soil erosion has compromised agricultural productivity, environmental biodiversity and food safety for the world's population. It is important to identify vulnerable areas to soil erosion in each region to initiate remedial measures. This study demonstrates the use of watershed morphometry coupled with weighted sum analysis (WSA) to estimate the soil erosion susceptibility of the Imo River Basin sub-watersheds (SWs) in South-Eastern Nigeria using satellite remote-sensing data and geographic information system (GIS) analysis. To this end, Shuttle Radar Topography Mission (SRTM), a Digital Elevation Model (DEM) with $30 \mathrm{~m}$ spatial resolution was used to extract and analyse 18 morphometric parameters including basic, linear, shape and relief. The method of receiver operating characteristics (ROC) curves was used to validate the model's prediction accuracy. This morphometry-based analysis resulted in the SWs being classified into zones of low, medium, high and very high erosion susceptibility. With regard to erosion susceptibility, $41.51 \%$ of the basin $\left(2494.68 \mathrm{~km}^{2}\right)$ is in the very high priority zone; while $10.50 \%, 44.33 \%$ and $3.66 \%$ of the basin are in the high, medium and low priority zones respectively. Validation of the final erosion susceptibility map showed a prediction accuracy of $81 \%$. The use of satellite imagery and morphometric analysis in this study was cost- and time-effective for identifying areas susceptible to soil erosion.
\end{abstract}

KEYWORDS: morphometry, weighted sum analysis, soil erosion susceptibility, SRTM, remote sensing, GIS, Imo River Basin

Corresponding author: Caleb O. Ogbeta,ogbetac@gmail.com

\section{Introduction}

Soil is a limited resource that is important for food production, carbon sequestration, water and nutrient management, contaminant filtration, biodiversity improvement, strong heritage, and climate regulation (Arshad, Martin 2002, Panagos et al. 2019). Due to population growth, economic progress and climate change, global soils are continually degrading (Montanarella et al. 2016). Soil erosion is a major cause of soil degradation as some forms of soil erosion by water (e.g. rill and gully) affect over 1 billion hectares globally (Lal 2003, Panagos et al. 2019). Anthropogenic activities as well as the resulting land-use changes (vegetation loss and growth in cropland) were the key reasons for a $2.5 \%$ rise in soil erosion by water between 2001 and 2012 (Borrelli et al. 2017). 
The impacts of soil erosion go further than marginal land degradation. It has contributed to increased contamination and sedimentation in streams and rivers, blocking up these waterways and causing losses in the population of fish and other aquatic animals. Soil erosion impacts agricultural productivity, drinking water resource quality, soil and aquatic ecosystem health, and landscape aesthetic value (Fayas et al. 2019). The effect of water-driven soil erosion on the global market and food supply reflects an estimated financial loss of USD 8-40 billion, a decrease in food production of 33.7 million tonnes and a 48 billion cubic metres rise in water usage (Sartori et al. 2019). In nations such as Brazil, China, India and low-income households worldwide, these impacts are felt more intensely (Nkonya et al. 2016, Sartori et al. 2019). Cumulative expenditure projections to minimize the on-site impacts of land degradation (e.g. production losses) and its off-site implications (e.g. biodiversity losses and water body siltation) contribute to values of USD 400 billion per annum (Nkonya et al. 2016). However, these numerical values were obtained in soil loss studies utilising Universal Soil Loss Equation (USLE) or related techniques, without any consideration of gully erosion (Alencar et al. 2020).

With a view to sustainable development and environmental conversation, soil erosion by water has been highlighted as a vital issue to be confronted in the 21st century (Borrelli et al. 2017, Poesen 2018, Alencar et al. 2020). A global model by Borrelli et al. (2020) predicts that by the year 2070, soil erosion will massively increase from $30 \%$ to $66 \%$, relative to the year 2015 estimates. The study also predicts that over 28 billion additional metric tons of soil will be lost annually if farming methods are not adjusted and steps are not taken to prevent climate change. This is about two-thirds $>43$ billion tons estimated for the year 2015. Tropical and sub-tropical countries with low to medium incomes are most vulnerable to a dramatic rise in erosion (Borrelli et al. 2020). In many parts of the world, extensive gully erosion caused by poor land management practices has had significant environmental effects. The contribution of gully erosion to the total soil loss from water erosion ranges from $10 \%$ to $94 \%$ worldwide, and in agricultural watersheds, it can account for up to $80 \%$ of the total soil erosion
(Capra, Scicolone 2002, Poesen et al. 2003, Gao et al. 2013). According to Nigeria Erosion and Watershed Management Program (NEWMAP) (2012), southern Nigeria is affected by massive gully erosion and there are an estimated 3000 gullies in rural or urban landscapes within the region. It is therefore critical for researchers and policymakers of these countries to explore erosion extent, identify possible hotspots, and work with stakeholders to soften the impact.

Poesen et al. (2003) identified gully erosion as a process that characterises runoff water which accumulates and often reoccurs in narrow channels and, over short periods thereby removing the soil from the narrow region to sizeable depths. Bernard et al. (2010) described the process of gully erosion as a mechanism that primarily starts during extreme rainfall events by eroding one channel or a series of channels due to the intensity of surface water discharge. Gullies contribute to land loss and desertification, as well as growing threats to the environment and society. Since the early 20th century, soil degradation has been a concern and according to estimates by the United States Department of Agriculture (USDA) and the National Conservation Congress, over $44,000 \mathrm{~km}^{2}$ of global land has been abandoned due to extreme erosion (Alencar et al. 2020). This number had risen to over $200,000 \mathrm{~km}^{2}$ by the end of the 1930s (Alencar et al. 2020).

Among soil erosion mechanisms, gully erosion has a significant contribution to watershed sedimentological processes, as it is also the primary cause of sediment displacement (Vanmaercke et al. 2016). Gullies also influence catchment connectivity (Verstraeten et al. 2006), enabling more sediments to enter water-bodies and therefore increasing siltation (De Arajuo et al. 2006). As they are extremely important in respect to erosion processes, gullies impose huge pressures on landscape development altering flood levels, increasing runoff and altering sediment dynamics (Valentin et al. 2005, Poesen 2018, Yibeltal et al. 2019). Gullies are also a major threat to humanity and its environment due to their effect on agricultural production, water availability, flooding, rubble flow and avalanches (Liu et al. 2016, Wei et al. 2018). Moreover, gullies do have a significant effect on the economy due to high costs of mitigation, reduced arable land, decreased freshwater reserves, improved connectivity of water 
and sediment, and severe salinity of reservoirs. (Verstraeten et al. 2006, Pinheiro et al. 2016). The evaluation of the effects of gullies on production costs in an arid area of Israel showed that the expense of mitigating gullies accounted for over $5 \%$ of total investments and that production losses were as high as 37\% (Valentin et al. 2005).

The mapping of erosion hazards is an important step for erosion control. A literature survey shows evidence of previous studies in this regard. For example, Nwilo et al. (2011) utilised Geographic Information Systems (GIS) as a method for identifying and mapping gully erosion hazards in Abia State, south-eastern Nigeria. A total of 171 gully erosion sites were coordinated using Global Positioning System (GPS) receivers, and a further 35 gully erosion sites were identified from a processed Digital Elevation Model (DEM). Relatedly, Okereke and Onu (2012) used remote sensing techniques to map the incidence of gully erosion in Okigwe, South-East Nigeria. In another study, Anejionu et al. (2013) adopted the Revised Universal Soil Loss Equation (RUSLE) to conduct a long-term evaluation of erosion hotspots in Southeast Nigeria. The study classified the zone into five erosion risk groups, ranging from very high to very low and included a spatial distribution mapping of erosion blackspots in the study area. By using the Revised USLE model, Chuenchum et al. (2020) analysed the evolving patterns of soil erosion and sediment yield from the effects of climate and land-use changes in the Lancang-Mekong River Basin, Southeast Asia. In most areas of the lower Mekong River Basin, the evolving environment and land use scenarios showed greater soil erosion and sediment yield. The results from this study could likewise serve as a knowledge resource in addressing the erosion issues in that region and in mitigating the possible effects. Applying the updated USLE formula in a GIS graphical user interface, a comprehensive assessment of soil erosion in the Kelani River Basin, Sri Lanka, effectively provided a range of spatially separate management strategies to deter erosion in the basin (Fayas et al. 2019). The study classified the Kelani River basin into five erosion risk groups: low, moderate, high, very high and extremely high. In addition to the categorisation, it included thematic maps on RUSLE parameters with applications in targeted conservation measures. Other researchers have employed ground surveys for mapping erosion sites (Ofomata 1965, Ogbukagu 1976, Egboka, Okpoko 1984, Okagbue, Uma 1987, Akpokodje et al. 2010, Ezezika, Adetona 2011, Obiadi et al. 2011). However, the cumbersome nature of ground surveys including the high cost makes it a non-attractive option and not suitable for mapping extensive regions.

Morphometric mapping of drainage basins has been applied effectively over the last decade to classify sub-basins at various scales. It has found wide applications in the development, administration and prioritisation of sub-basins for soil and water management. Morphometry is the product of basic measurements and numerical modelling of soil surface setup, shape, and landform aspects (Adinarayana et al. 1995, Srivastava 2003, Jang et al. 2013). It is an essential element of hydrological and hydro-geological analysis (Agarwal 1998). It aids the understanding of hydrological characteristics, and its effects are useful inputs to a holistic approach for water resource conservation (Jawaharraj et al. 1998, Kumaraswami et al. 1998, Sreedevi et al. 2001). Morphometric analysis requires a calculation of the linear characteristics, channel network gradient, and contributing drainage basin ground slopes. It is an essential tool for prioritising sub-watersheds (SWs), without even considering the soil map (Biswas et al. 1999). Horton (1940) and Strahler (1950) conducted initial morphometric research in the field of hydrology. The movement of surface runoffs and sediments to a stream within the drainage basin is a basis for morphometric analysis (Chopra et al. 2005, Patel et al. 2013, Ameri et al. 2018). For example, Gajbhiye et al. (2014) used morphometric parameters to define critical sub-basins of the Manot river catchment of Madhya Pradesh in India, which were hurting from severe soil erosion. Ameri et al. (2018) also used morphometric parameters to prioritise the erodibility of 36 SWs of the Ghaemshahr Basin of Mazandaran Province in Iran. Rahaman et al. (2015) prioritised Kallar drainage basin SWs based on morphometric features, by using Fuzzy Analytic Hierarchy Process (AHP) and GIS.

It is evident that erosion poses a major challenge to the protection of soil and water supplies in South-Eastern Nigeria. Moreover, lasting results are yet to be attained by several government 
intervention efforts such as the Nigeria Erosion and Watershed Management Program (NEWMAP) which was set up to curb the erosion threat in the region. A literature survey has not shown any evidence of the use of morphometric parameters in comprehensively modelling erosion processes and prioritising erosion-prone areas of catchment zones within South-Eastern Nigeria. Decision-makers in government, policy strategists, and soil and water conservationists require an understanding of the location and magnitude of erosion occurrence, now and in the future. This study aims to apply morphometric analysis for identifying areas susceptible to soil erosion within the Imo River Basin of SouthEastern Nigeria. Erodibility prioritisation of SWs was carried out through ranking and correlation analysis using the modified weighted sum analysis (WSA) approach. This study seeks to inform efforts aimed at mitigating the risk of erosion both locally and internationally by contributing to the knowledge base on erosion mapping and management. This caters to the vision of the United Nation's Sustainable Development Goals (SDGs) for life on land, and sustainable cities and communities.

\section{Materials and methods}

\section{Study area}

The Imo River Basin in South-Eastern Nigeria, West Africa has a total area of $2494.68 \mathrm{~km}^{2}$. Geographically, it is located between latitudes $4^{\circ} 50^{\prime}-6^{\circ} 00^{\prime} \mathrm{N}$, and longitudes $7^{\circ} 05^{\prime}-7^{\circ} 35^{\prime} \mathrm{E}$. The Imo River originating from Okigwe in Imo State is the major river draining the basin (Amangabara 2015). The maximum elevation is found in the upper part of the basin with a height of $417 \mathrm{~m}$ above mean sea level (MSL), and the minimum height is in the lower part of the basin with a height of $5 \mathrm{~m}$ above MSL. The basin extent is shared by three dominant states namely - Imo, Abia and Rivers. Figure 1 presents a map showing the location of the Imo River Basin. The surrounding states have a hot, semi-hot equatorial type of climate. The area experiences heavy rainfall, with a mean annual precipitation of $2000-2400 \mathrm{~mm}$ and an average number of 152 rainy days especially during the wet season (April-October). The distribution of superficial precipitation is skewed, with highs in July and September and a 2-week break in August. The rainy season starts in March and lasts until October or early November (NIMET 2019). Rainfall also hits its highest at night and during the early morning hours. The greater annual levels of rainfall and days of rainfall contribute to significant amounts of runoff. Differences in the amount of rainfall happen from year to year, however, usually between 1990 and $2200 \mathrm{~mm}$ (NIMET 2019). As a result, agricultural practices require little irrigation. This also promotes luxuriant forests beyond agriculture and recharging water sources from the soil and surface. Relative humidity during the dry and rainy seasons alternates between 75 and $90 \%$. January to March are the hottest months, with annual average temperatures $>20^{\circ} \mathrm{C}$.

The Imo River Basin is predominantly occupied by the Igbo-speaking tribe. With good soil for agriculture and water for fishing, the main occupation is farming and fishing as it provides a source of livelihood to the populace. Extraction of minerals such as crude oil by both skilled and unskilled labourers are also important activities within the basin. Manufacturing industries abound in this region's metropolitan areas. The whole South-East zone falls within Nigeria's forest and derived savanna belt. Much of the forestland has been transformed into oil palm tree-dominated farmlands and palm bushes. The region's major environmental concerns are deforestation, soil erosion and biodiversity depletion (Okali et al. 2001).

\section{Data acquisition}

This study utilised the Shuttle Radar Topography Mission (SRTM) v3.0 Global DEM acquired from the United States Geological Survey (USGS) web portal (earthexplorer.usgs. gov $/$ ). The SRTM DEM is provided in $1 \times 1$ tiles at 1 arc-second $(30 \mathrm{~m})$ and is defined on WGS 84 datum. It is also referenced to the EGM96 geoid model. Hence its heights are orthometric with vertical units in metres. The SRTM DEM's global coverage provides tremendous advantages for wide-area environmental modelling, especially when data availability is a problem. SRTM v3.0 which was released in September 2014 reveals the total detail of the world's landforms as originally 


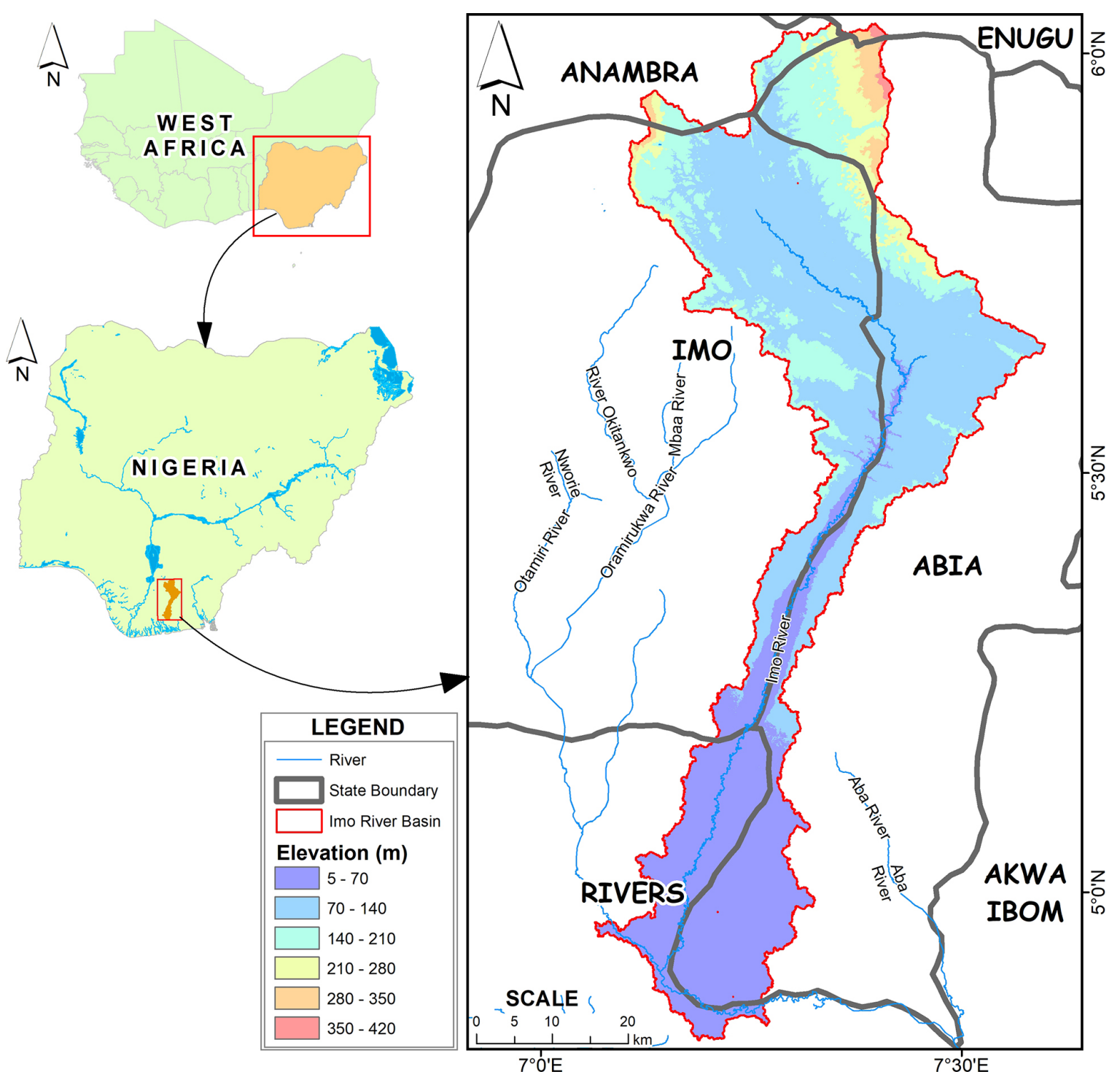

Fig. 1. Map showing the location of the study area.

captured by SRTM in the year 2000 (NASA JPL 2014). However, in providing reasonably reliable data to define drainage basin morphometry, several studies have shown that SRTM DEM is far better than the Advanced Spaceborne Thermal Emission and Reflection Radiometer (ASTER) DEM (Sun et al. 2003, Farr et al. 2007, Forkuor, Maathuis 2012, Patel et al. 2016). Figure 2 presents a workflow of the methodology.

\section{DEM pre-processing and watershed mapping}

DEM pre-processing is the first stage of the processing carried out on the DEM to make it more hydrologically correct and to improve on its terrain characterisation. The pre-processing
DATA ACQUISITION

Mission (SRTM) - 30m DEM was acquired from USGS online portal

DATA PRE-PROCESSING AND PROCESSING - DEM pre-processing - Watershed mapping
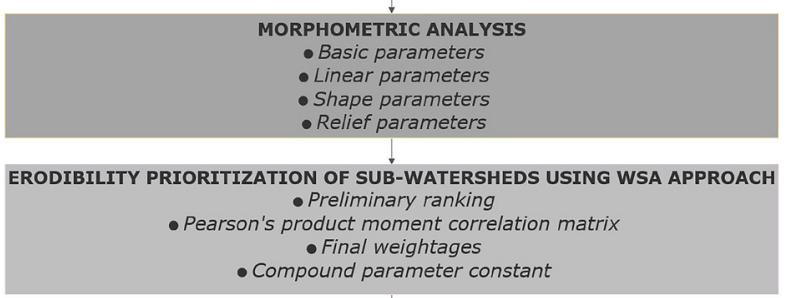

VALIDATION OF THE EROSION SUSCEPTIBILITY USING ROC CURVES

PRESENTATION OF RESULTS

Fig. 2: Methodology workflow. 
steps to be implemented are dependent on the type of terrain, and on the type of analysis to be carried out. The following pre-processing steps were executed within the ArcGIS 10.3 software environment - fill sinks, flow direction and flow accumulation. Thereafter, the watershed was delineated. The delineated watershed boundary was further segmented into SWs using the ArcHydro extension tools for ArcGIS 10.3. The drainage network of the SWs was extracted from the pre-processed DEM using the ArcHydro tools. ArcHydro uses a rational, efficient and reliable algorithm. In the next phase, the stream ranking (stream ordering) was carried out following the stream ranking system initially introduced by Horton (1945) and later amended by Strahler (1964). According to Strahler (1964), all rivers and streams of the fingertips are designated as streams of the first order and where two of them join; they form a stream of second order. Similarly, two streams of the second order join to form a stream of the third order, and so forth. Stream order increases only when streams of the same order converge. The convergence of a first-order and second-order link will therefore remain a second-order link, instead of creating a third-order link. The categorisation of rivers and streams within drainage basins can be accomplished by conventional methods such as using topographic maps and ground observations, or by using advanced techniques such as remote sensing and GIS (Macka 2001, Maidment 2002, Altaf et al. 2014).

\section{Morphometric analysis}

The morphometric analysis includes linear character estimation, channel network slope and contributing drainage basin ground slopes (Nautiyal 1994). The morphometric analysis for the different sub-basins was carried out by measuring the linear, shape and relief morphometric parameters of the basin. Areas and perimeters of the SWs were assessed by measuring the geometry of the derived sub-watershed polygons in the ArcGIS environment. Morphometric analysis is based on the overall drainage system activity. The drainage pattern refers to the spatial correlation between streams or rivers which may be impacted by the region's steepness, soil, rock rigidity, framework and geological history inequalities in their erosion. The morphometric research uses some very important elements (linear, shape and relief parameters) to prioritise the SWs in water supply management. In this study, extraction and evaluation of the morphometric parameters in each of the SWs were ranked using their relationship to soil erodibility. The overall number of ranks assigned in this method is based upon the number of watersheds. Ranks were numbered from 1 to 25, based on the number of SWs delineated. Rank 1 was assigned in such a way that the parameter value represents the maximum contribution to erodibility and rank 25 is a minimum contribution. The formulas used to derive the necessary morphometric parameters pertaining to linear, areal, and relief aspects of the watershed are presented in Table 1.

\section{Erodibility prioritisation of SWs using WSA approach}

Erodibility prioritisation is the hierarchical ranking of various SWs in relation to soil erodibility, and the required soil and water conservation measures are taken according to the priority order. The WSA approach is effective and ideally suited to prioritizing watersheds. In the present study, sub-watershed wise delineation was done by using a newly developed prioritisation methodology where geospatial approaches are coupled with a statistical approach to allow the correct sub-watershed ranking, by avoiding the individual bias associated with several influencing parameters. Various morphometric parameters were rated in this method in terms of their relationship with erodibility, and correlation analysis among these parameters was performed. Therefore, it is hypothesised that an incentive exists to rectify the incorrect findings in order to increase the prioritisation accuracy. This method was useful in generating and assigning weights to each input variable according to their significance.

Secondly, the correlation between erosion assessment (morphometric) parameters using Pearson's product-moment correlation (r) was identified. The sum of all correlations in the columns was calculated and recognised as 'sum of correlation'. The totals of the 'sum of correlation' yielded the 'grand total'. Also, the final weights $(\mathrm{Fw})$ of the morphometric parameters were 
calculated by dividing the 'sum of the correlation coefficient' of each parameter by the grand total of correlations (Table 6).

The Fw were calculated using Eq. (1).

Final weight $($ Fwi $)=\frac{\text { Sum of correlation coefficient }}{\text { Grand total of correlations }}$

Finally, using Eq. (2), the compound parameter constant $(\mathrm{Cpc})$ values of all SWs in the ImoRiver Basin were calculated based on the weights of each morphometric parameter (metrics). A final erosion susceptibility map of the study area was prepared using the $\mathrm{Cpc}$ values.

$$
\mathrm{Cpc}=\sum(\operatorname{Pr} i \times \mathrm{Fw} i)
$$

where:

- Pri is the preliminary rank of $i$ th parameter for sub-watershed, and

- Fwi is the final weight of the same ith parameter.

Table 1. Formulas adapted for the computation of morphometric parameters.

\begin{tabular}{|c|c|c|c|c|}
\hline $\mathrm{S} / \mathrm{N}$ & $\begin{array}{l}\text { Morphometric } \\
\text { parameter }\end{array}$ & Formula & Unit & Reference \\
\hline 1 & Basin area $(\mathrm{A})$ & The area enclosed by the watershed (GIS software analysis) & $\mathrm{km}$ & Horton (1945) \\
\hline 2 & Basin perimeter $(\mathrm{P})$ & The perimeter of the watershed (GIS software analysis) & $\mathrm{km}$ & Horton (1945) \\
\hline 3 & Basin length $(\mathrm{Lb})$ & $\begin{array}{l}\text { Distance from outlet to the farthest point on basin boundary } \\
\text { (GIS software analysis) }\end{array}$ & $\mathrm{km}$ & $\begin{array}{l}\text { Schumm } \\
(1956)\end{array}$ \\
\hline 4 & Stream order $(\mathrm{U})$ & Hierarchical order & {$[-]$} & Strahler (1964) \\
\hline 5 & $\begin{array}{l}\text { Number of streams } \\
(\mathrm{Nu})\end{array}$ & Total stream number of all orders (GIS software analysis) & {$[-]$} & Strahler (1964) \\
\hline 6 & $\begin{array}{l}\text { Total stream length } \\
\text { (L) }\end{array}$ & Total stream length of all orders & $\mathrm{km}$ & Horton (1945) \\
\hline 7 & $\begin{array}{l}\text { Bifurcation ratio } \\
\qquad(\mathrm{Rb})\end{array}$ & $\begin{array}{c}\qquad \mathrm{Rb}=\mathrm{Nu} /(\mathrm{Nu}+1) \\
\text { where } \mathrm{Rb}=\text { Bifurcation ratio; } \mathrm{Nu}=\text { Total no. of stream seg- } \\
\text { ments of order ' } \mathrm{u} \text { '; } \mathrm{Nu}+1=\mathrm{Number} \text { of segments of the next } \\
\text { higher order. }\end{array}$ & {$[-]$} & $\begin{array}{l}\text { Schumm } \\
\text { (1956) }\end{array}$ \\
\hline 8 & $\begin{array}{l}\text { Mean bifurcation } \\
\text { ratio (Rbm) }\end{array}$ & $\mathrm{Rbm}=$ Average of bifurcation ratios of all orders & {$[-]$} & Strahler (1957) \\
\hline 9 & $\begin{array}{l}\text { Drainage density } \\
\text { (Dd) }\end{array}$ & $\begin{array}{c}\mathrm{D}=\mathrm{Lu} / \mathrm{A} \\
\text { where } \mathrm{D}=\text { Drainage density; } \mathrm{Lu}=\text { Total stream length of all } \\
\text { orders; } \mathrm{A}=\text { Basin area }\left(\mathrm{km}^{2}\right)\end{array}$ & $\begin{array}{c}\mathrm{km} \\
\mathrm{km}^{-2}\end{array}$ & Horton (1945) \\
\hline 10 & $\begin{array}{l}\text { Stream frequency } \\
(\mathrm{Fs})\end{array}$ & $\begin{array}{c}\mathrm{Fs}=\mathrm{Nu} / \mathrm{A} \\
\text { where } \mathrm{Fs}=\text { Stream frequency; } \mathrm{Nu}=\text { Total no. of streams of all } \\
\text { orders; } \mathrm{A}=\text { Basin area }\left(\mathrm{km}^{2}\right)\end{array}$ & $\begin{array}{c}\text { no } \\
\mathrm{km}^{-2}\end{array}$ & Horton (1945) \\
\hline 11 & $\begin{array}{l}\text { Drainage texture } \\
\text { (Dt) }\end{array}$ & $\begin{array}{c}\mathrm{Dt}=\mathrm{Nu} / \mathrm{P} \text { where } \mathrm{Dt}=\text { Drainage texture; } \mathrm{Nu}=\text { Total no. of } \\
\text { streams of all orders; } \mathrm{P}=\text { Basin Perimeter }(\mathrm{km})\end{array}$ & $\begin{array}{c}\text { no } \\
\mathrm{km}^{-1}\end{array}$ & Horton (1945) \\
\hline 12 & $\begin{array}{l}\text { Elongation ratio } \\
\qquad(\operatorname{Re})\end{array}$ & $\begin{array}{c}\operatorname{Re}=2 / \mathrm{Lb} \text { sqrt }(\mathrm{A} / \Pi) \\
\text { where } \operatorname{Re}=\text { Elongation ratio; } \mathrm{A}=\text { Basin area }\left(\mathrm{km}^{2}\right) ; \Pi=\text { 'Pi' } \\
\text { value i.e. 3.14; } \mathrm{Lb}=\text { Basin length }\end{array}$ & {$[-]$} & $\begin{array}{l}\text { Schumm } \\
\text { (1956) }\end{array}$ \\
\hline 13 & $\begin{array}{l}\text { Circulatory ratio } \\
\qquad(\mathrm{Rc})\end{array}$ & $\begin{array}{c}\mathrm{Rc}=4 \times \Pi \times \mathrm{A} / \mathrm{P}^{2} \\
\text { where } \mathrm{Rc}=\text { Circularity ratio; } \Pi={ }^{\prime} \mathrm{Pi}^{\prime} \text { value i.e. } 3.14 ; \mathrm{A}=\text { Basin } \\
\text { area }\left(\mathrm{km}^{2}\right) ; \mathrm{P}=\text { Basin Perimeter }(\mathrm{km})\end{array}$ & {$[-]$} & Miller (1953) \\
\hline 14 & Form factor (Rf) & $\begin{array}{c}\mathrm{Rf}=\mathrm{A} / \mathrm{Lb}^{2} \\
\text { where } \mathrm{Rf}=\text { Form factor; } \mathrm{A}=\text { Basin area }\left(\mathrm{km}^{2}\right) ; \mathrm{Lb}^{2}=\text { Square of } \\
\text { basin length }\end{array}$ & {$[-]$} & Horton (1932) \\
\hline 15 & $\begin{array}{l}\text { Compactness coeffi- } \\
\text { cient }(\mathrm{Cc})\end{array}$ & $\begin{array}{c}\mathrm{Cc}=\mathrm{P} / 2 \operatorname{sqrt}(\Pi \mathrm{A}) \\
\text { where } \mathrm{Cc}=\text { Compactness Coefficient; } \mathrm{P}=\text { Basin perimeter } \\
(\mathrm{km}) ; \mathrm{A}=\text { Basin area }\left(\mathrm{km}^{2}\right)\end{array}$ & {$[-]$} & Horton (1945) \\
\hline 16 & Basin Relief $(\mathrm{H})$ & $\mathrm{H}=$ Maximum relief - Minimum relief & $\mathrm{m}$ & Horton (1945) \\
\hline 17 & Relief ratio $(\mathrm{Rh})$ & $\begin{array}{c}\qquad \mathrm{Rh}=\mathrm{H} / \mathrm{Lb} \\
\text { where } \mathrm{Rh}=\text { Relief ratio; } \mathrm{H}=\text { Basin relief; } \mathrm{Lb}=\text { Basin length }\end{array}$ & {$[-]$} & $\begin{array}{l}\text { Schumm } \\
(1956)\end{array}$ \\
\hline 18 & $\begin{array}{l}\text { Ruggedness number } \\
\text { (Rn) }\end{array}$ & $\begin{array}{c}\qquad \mathrm{Rn}=\mathrm{Dd} \times(\mathrm{H} / 1000) \\
\text { where Rn = Ruggedness Number; } \mathrm{Dd}=\text { Drainage density; } \\
\mathrm{H}=\text { Basin relief }\end{array}$ & {$[-]$} & Strahler (1968) \\
\hline
\end{tabular}




\section{Validation of the erosion susceptibility}

To systematically and qualitatively evaluate the erosion susceptibility metrics, the method of receiver operating characteristics (ROC) curves was used to evaluate the model's prediction accuracy. ROC curves are useful in evaluating the performance of binary classifiers (Zhang et al. 2015) and can discriminate between the observed and predicted variables based on the logistic regression S-shaped curve. This validation technique is also known as relative operating characteristics (Pontius, Schneider 2001). The ROC curve technique follows a binary classification rule which results in four potential outcomes: true positive, true negative, false positive, and false negative. If a correct outcome is properly identified as positive, a true positive exists, while a false positive defines a negative outcome as being incorrectly positive. On the negatives, if a negative outcome is properly recognised as negative, a true negative exists, and a false negative wrongly recognises a true result as negative (Carter et al. 2016). The relationship between the sensitivity and 1 specificity is graphically represented as the ROC curve and the area under the curve (AUC) is the accuracy of the predicted results. Sensitivity is characterised as the measure of positives correctly identified as such or the likelihood of a positive test, often referred to as the true-positive rate Eq.
(3). Specificity is the proportion of negatives correctly classified as such or the possibility of a negative test. This is also referred to as the true-negative rate. The false positive rate ( 1 - specificity) is the proportion of incorrect positive results that are actually negative Eq. (4). The false negative rate $(1$ - sensitivity) is the proportion of incorrect results that are actually positive (Nelson et al. 2005). By plotting the true-positive rate (sensitivity) on the $y$-axis against the false-positive rate ( 1 - specificity) on the $\mathrm{x}$-axis, ROC curves are formed.

True positive rate $=\frac{\text { True positives }}{\text { True positives }+ \text { false negatives }}$

False positive rate $=\quad$ True negatives

True negatives + false positives

For the validation of the erosion susceptibility result, the locations of prevalent erosional occurrences (shown in Table 2) were obtained from the literature and records of recent events from online sources (Amangabara et al. 2015, Amangabara et al. 2018, Channels Television 2018). With this technique, the ROC curve tool embedded in the SPSS software environment was deployed and the ROC curve plot was produced where the AUC was determined. The coordinates of the curve are shown in Table 3.

Table 2. Descriptive information of the validation points.

\begin{tabular}{|c|c|c|c|c|c|c|c|}
\hline Point & & \multirow{2}{*}{$\begin{array}{l}\text { Erosion } \\
\text { type }\end{array}$} & Easting & Northing & Average depth & Area & \multirow{2}{*}{ Source(s) } \\
\hline no. & Location name & & {$[\mathrm{mE}]$} & {$[\mathrm{mN}]$} & {$[\mathrm{m}]$} & {$\left[\mathrm{km}^{2}\right]$} & \\
\hline 1 & Ideato North & \multirow{5}{*}{$\begin{array}{l}\text { Gully } \\
\text { erosion }\end{array}$} & 297084 & 650725 & $15-35$ & $30.11-109.72$ & \multirow{3}{*}{$\begin{array}{l}\text { (Amangabara et al. 2015, } \\
\text { Amangabara et al. 2018) }\end{array}$} \\
\hline 2 & Ideato South & & 296988 & 643359 & $15-35$ & $30.11-109.72$ & \\
\hline 3 & Okigwe & & 317303 & 643221 & - & 0.68 & \\
\hline 4 & Obowo & & 319395 & 616106 & $05-20$ & $8.39-30.12$ & \multirow[t]{2}{*}{ Amangabara et al. (2015) } \\
\hline 5 & Ehime Mbano & & 309899 & 628529 & - & $0.55-2.09$ & \\
\hline 6 & Umuahia North & \multirow{2}{*}{$\begin{array}{l}\text { Gully } \\
\text { erosion }\end{array}$} & 332166 & 617607 & - & $6.85-31.70$ & \multirow[t]{2}{*}{ Channels Television (2018) } \\
\hline 7 & Aboh-Mbaise & & 309726 & 593501 & - & $0.76-1.53$ & \\
\hline 8 & Unuimo & \multirow{6}{*}{$\begin{array}{l}\text { No active } \\
\text { erosion }\end{array}$} & 303363 & 636918 & - & - & - \\
\hline 9 & Ogwe & & 306703 & 551110 & - & - & - \\
\hline 10 & Obiaku & & 301950 & 540063 & - & - & - \\
\hline 11 & Nkpa & & 333293 & 623302 & - & - & - \\
\hline 12 & Ihitte-Uboma & & 316080 & 623687 & - & - & - \\
\hline 13 & Etche & & 293472 & 547770 & - & - & - \\
\hline
\end{tabular}

Table 3. Coordinates of the ROC curve.

\begin{tabular}{|l|c|c|c|c|c|c|c|c|c|c|c|c|}
\hline \multicolumn{1}{|c|}{ S/N } & 1 & 2 & 3 & 4 & 5 & 6 & 7 & 8 & 9 & 10 & 11 & 12 \\
\hline Sensitivity & 1.000 & 1.000 & 1.000 & 1.000 & 0.833 & 0.667 & 0.500 & 0.333 & 0.333 & 0.333 & 0.167 & 0.000 \\
\hline 1 - Specificity & 1.000 & 0.714 & 0.429 & 0.286 & 0.286 & 0.286 & 0.286 & 0.286 & 0.143 & 0.000 & 0.000 & 0.000 \\
\hline
\end{tabular}




\section{Results and discussion}

\section{SWs analysis}

The watershed processing resulted in the delineation of the Imo River Basin with 25 SWs. Figure 3 presents a map showing the basin's SWs, with SW5 $\left(656.12 \mathrm{~km}^{2}\right)$ being the largest sub-watershed and SW6 $\left(35.53 \mathrm{~km}^{2}\right)$ being the smallest sub-watershed in terms of areal extent. The Imo River which is the major river in the basin has its source in the Okigwe upland located in SW16, and flows north to south through SW15, SW14, SW10, SW8, SW7, SW5, SW3 downwards to the basin outlet (SW1). The river flows across some major towns such as Okigwe, Abekenta, Ugwuaku, Umuzi, Ezinachi, Ife, Okpuala and Abiama in each SW, having its longest length of flow $(105 \mathrm{~km})$ in SW5. It is joined at SW3 by its major tributary (Otamiri River) flowing from the north and exits the basin at SW1.

\section{Analysis of basic parameters}

The results of the computation of basic morphometric parameters are shown in Table 4. The drainage networks in the Imo River Basin transport water and sediments of the basin through a single outlet (Imo River), which is marked as the maximum order of the basin and conventionally the highest order stream (6th order) available in the basin considered as the order of the basin. Based on stream order, Imo River Basin was graded as 6th order with an area of $2494.68 \mathrm{~km}^{2}$ and a perimeter of $746.72 \mathrm{~km}$. Figure 4 presents a map showing the basin's stream order. The cumulative number of streams in the basin is 1954 . The total length of the streams in various orders is $2746.06 \mathrm{~km}$.

Some of the morphometric parameters are directly considered as soil erosion metrics and thus are referred to as erosion risk assessment parameters (Biswas et al. 1999). These include the

Table 4. Basic parameters of sub-watersheds (SWs) in the Imo River Basin.

\begin{tabular}{|c|c|c|c|c|c|c|c|}
\hline \multirow{3}{*}{ Sub-watershed ID } & \multirow{2}{*}{ Basin area } & \multirow{2}{*}{ Basin perimeter } & \multirow{2}{*}{ Basin length } & \multirow{2}{*}{ No. of streams } & \multirow{2}{*}{ Total stream length } & \multicolumn{2}{|c|}{ Elevation } \\
\hline & & & & & & $\operatorname{Max}$ & Min \\
\hline & {$\left[\mathrm{km}^{2}\right]$} & \multicolumn{2}{|c|}{$[\mathrm{km}]$} & {$[-]$} & {$[\mathrm{km}]$} & \multicolumn{2}{|c|}{$[\mathrm{m}]$} \\
\hline SW1 & 51.97 & 75.23 & 11.27 & 37 & 51.43 & 41 & 12 \\
\hline SW2 & 39.24 & 50.30 & 8.33 & 26 & 40.75 & 37 & 14 \\
\hline SW3 & 103.93 & 104.85 & 16.51 & 84 & 113.91 & 52 & 18 \\
\hline SW4 & 158.62 & 117.01 & 22.45 & 128 & 180.71 & 70 & 17 \\
\hline SW5 & 656.12 & 351.57 & 69.97 & 548 & 757.62 & 193 & 20 \\
\hline SW6 & 35.53 & 48.99 & 11.95 & 29 & 35.00 & 186 & 67 \\
\hline SW7 & 137.12 & 112.25 & 15.56 & 102 & 139.73 & 206 & 60 \\
\hline SW8 & 56.51 & 58.75 & 10.11 & 49 & 60.28 & 203 & 67 \\
\hline SW9 & 67.16 & 57.89 & 10.46 & 63 & 77.83 & 175 & 81 \\
\hline SW10 & 50.87 & 51.22 & 10.44 & 36 & 48.03 & 212 & 75 \\
\hline SW11 & 89.84 & 79.12 & 12.13 & 70 & 90.71 & 240 & 73 \\
\hline SW12 & 83.18 & 64.30 & 11.21 & 79 & 86.64 & 219 & 82 \\
\hline SW13 & 53.53 & 52.09 & 12.76 & 26 & 55.09 & 286 & 75 \\
\hline SW14 & 60.49 & 56.84 & 10.96 & 51 & 66.94 & 290 & 76 \\
\hline SW15 & 58.19 & 69.55 & 13.51 & 48 & 62.12 & 330 & 82 \\
\hline SW16 & 63.83 & 62.58 & 14.73 & 39 & 69.49 & 334 & 83 \\
\hline SW17 & 116.86 & 76.83 & 13.38 & 99 & 133.21 & 262 & 89 \\
\hline SW18 & 83.69 & 107.19 & 14.88 & 67 & 85.68 & 239 & 86 \\
\hline SW19 & 59.31 & 55.17 & 13.47 & 37 & 66.98 & 360 & 99 \\
\hline SW20 & 68.98 & 52.21 & 10.58 & 51 & 71.15 & 323 & 118 \\
\hline SW21 & 55.77 & 72.08 & 14.31 & 40 & 76.02 & 322 & 99 \\
\hline SW22 & 78.38 & 102.44 & 24.19 & 48 & 80.23 & 386 & 86 \\
\hline SW23 & 47.47 & 80.10 & 18.18 & 37 & 50.74 & 345 & 104 \\
\hline SW24 & 124.73 & 106.08 & 18.73 & 85 & 135.74 & 417 & 109 \\
\hline SW25 & 93.37 & 68.50 & 13.43 & 75 & 110.06 & 416 & 149 \\
\hline
\end{tabular}




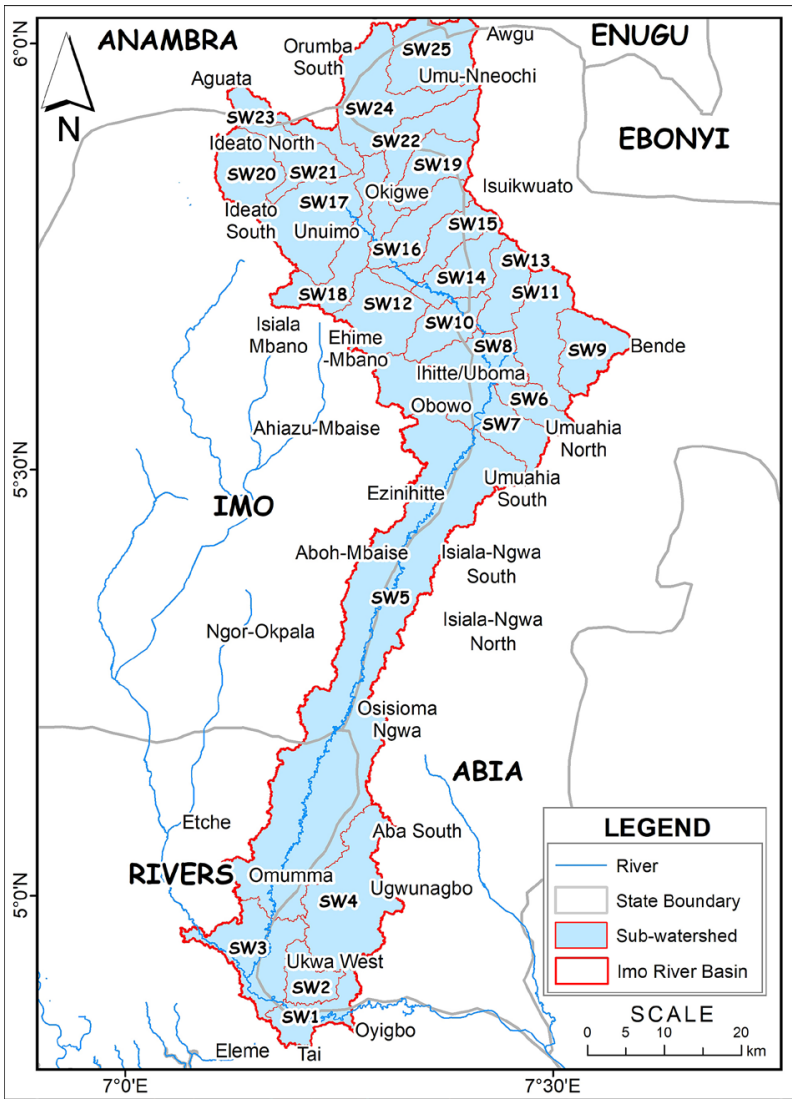

Fig. 3. Sub-watershed map of Imo River Basin.

linear, shape and relief morphometric parameters as shown in Table 5. Linear and relief morphometric parameters have a direct/positive association with erodibility, i.e. the higher the values of these parameters, the greater the erodibility in the area and vice versa (Javed et al. 2009). In contrast, shape morphometric parameters have an inverse relation to erodibility i.e. the lower the values of these parameters, the higher the erodibility in the field of analysis and vice versa (Ratnam et al. 2005).

\section{Analysis of linear morphometric parameters}

These parameters include Drainage density (Dd), Stream frequency (Fs), Mean Bifurcation ratio (Rbm), and Drainage texture (Dt). A lower Dd in any watershed implies a porous sub-surface soil, strong vegetation-cover, low-relief and vice-versa (Harlin, Wijeyawickrema 1985, Nag, Chakraborty 2003, Prasad et al. 2008, Vaidya et al. 2013, Farhan, Anaba 2016, Farhan et al. 2017, Ali et al. 2018). A study by Asfaw and Workineh (2019) on Gumara and Ribb watershed, Ethiopia, shows a Dd of $0.26 \mathrm{~km}^{-1}$ and $0.30 \mathrm{~km}^{-1}$ which is

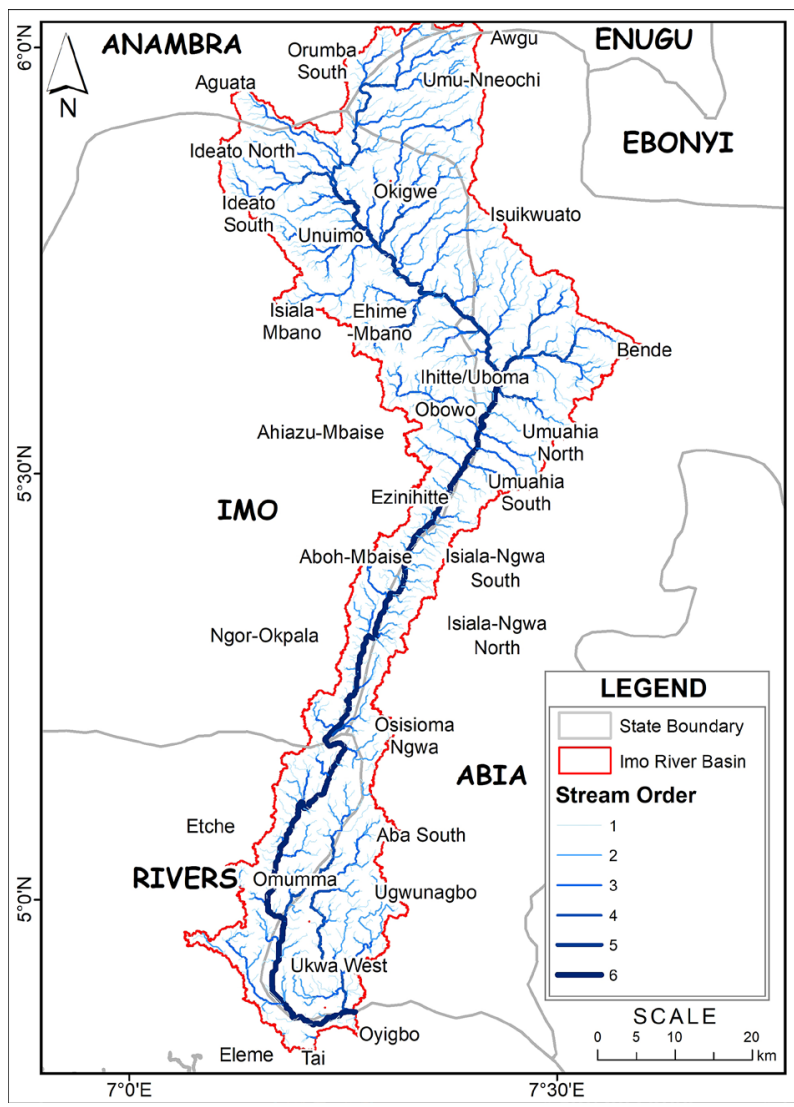

Fig. 4. Drainage map of Imo River Basin showing the stream order.

low and implies that the basin experience highly permeable sub-surface, low erosion exposure and better groundwater potential. Similarly, in the Imo River Basin, the lowest volume of Dd was observed in SW10 $\left(0.94 \mathrm{~km}^{-1}\right)$, which indicates that this sub-watershed has a high degree of porosity among the other SWs, or it has the highest tendency to resist erosion if only the drainage parameter is taken as a metric for susceptibility to erosion.

The Fs has an inverse correlation with porosity and a positive correlation to watershed relief (Montgomery, Dietrich 1992). High Fs indicates that there is rocky terrain in the watershed and low infiltration ability which correlates to further erosion and vice versa (Altaf et al. 2014). In the Imo River Basin, the Fs ranges from $0.49 \mathrm{~km}^{-2}$ for SW13 to $0.95 \mathrm{~km}^{-2}$ for SW12. Based on the Fs, these results indicate that SW12 has the least infiltration capacity and hence, the highest susceptibility to erosion while SW13 has the least erosion susceptibility in terms of Fs only. The Rbm is a measure of the terrain's structural complexity and porosity and is thus negatively associated 
Table 5. Linear, shape and relief parameters of sub-watersheds (SWs) in the Imo River Basin and its preliminary ranking with respect to soil erodibility.

\begin{tabular}{|c|c|c|c|c|c|c|c|c|c|c|c|}
\hline \multirow{2}{*}{$\begin{array}{l}\text { Sub- } \\
\text { water- } \\
\text { shed }\end{array}$} & \multicolumn{4}{|c|}{ Linear parameters } & \multicolumn{4}{|c|}{ Shape parameters } & \multicolumn{3}{|c|}{ Relief parameters } \\
\hline & $\mathrm{Dd}$ & Fs & $\mathrm{Rbm}$ & Dt & $\operatorname{Re}$ & Rc & $\mathrm{Rf}$ & Cc & $\mathrm{H}$ & $\mathrm{Rh}$ & $\mathrm{Rn}$ \\
\hline SW1 & & $71(18)$ & $5.57(2)$ & 3) & $72(14)$ & & & & & & \\
\hline & & & & & & & & & & & \\
\hline N3 & & & & & & & & & & & \\
\hline$\sqrt{ } 4$ & & & & & & & & & & & \\
\hline$S$ & & & & & & & & & & & \\
\hline$s$ & & & & & & & & & & & \\
\hline SW & & & & & & & & & & & \\
\hline SW & & & & & & & & & & & \\
\hline & & & & & & & & & & & \\
\hline & & & & & & & & & & & \\
\hline & & & & & & & & & & & \\
\hline SW1 & & & & & & & & & & & \\
\hline SW1 & & & & & & & & & & & \\
\hline & & & & & & & & & & & \\
\hline & & & & & & & & & & & \\
\hline & & & & & & & & & & & \\
\hline & & & & & & & & & & & \\
\hline & & & & & & & & & & & \\
\hline & & & & & & & & & & & \\
\hline SW20 & $03(17)$ & & & & & & & & & & \\
\hline SW21 & & & $4.14(14)$ & 0) & & & & & & & \\
\hline SW22 & & & & $0.47(24)$ & & & & & & & \\
\hline SW23 & & & & $0.46(25)$ & & & & & & & \\
\hline SW24 & 09 (11) & $68(20)$ & $4.03(15)$ & $0.80(12)$ & & & & & & & \\
\hline 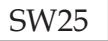 & $1.10(2)$ & $0.80(11)$ & $3.91(18)$ & $1.10(4)$ & $0.81(17)$ & $0.25(22)$ & $0.52(17)$ & $2.01(4)$ & $267(3)$ & $0.020(1)$ & $0.315(2)$ \\
\hline
\end{tabular}

Preliminary ranks are shown in brackets.

Dd - drainage density; Fs - stream frequency; Rbm - mean bifurcation ratio; Dt - drainage texture; Cc - compactness coefficient; $\mathrm{Re}$ - elongation ratio; $\mathrm{Rc}$ - circulatory ratio; $\mathrm{Rf}$ - form factor; $\mathrm{H}$ - total basin relief; $\mathrm{Rh}$ - relief ratio; $\mathrm{Rn}$ ruggedness number.

with the watershed's porosity. High Rbm suggests early hydrographic optimum with capacity for flood events during heavy rains leading to the deterioration of the soil surface (Howard 1990). Rbm's connection to an area's susceptibility to erosion is the same as that conveyed by Dd and Fs. Hence in this instance, the classification was the same as in the case of Dd and Fs. In the Imo River Basin, the Rbm ranges from 3.11 for SW11 to 6.44 for SW22. SW22 has the highest susceptibility to erosion in the study area according to Rbm results. The final linear morphometric parameter is the Drainage texture $(\mathrm{Dt})$ that is strongly affected by the infiltration ability (Horton 1945). Low-infiltration regions will produce higher Dt and thus result in more erosion. The sub-watershed with the highest value of Dt in the Imo River Basin is SW5 $\left(1.56 \mathrm{~km}^{-1}\right)$, indicating that it is the most susceptible to erosion due to a low infiltration rate. The sub-watershed with the lowest Dt is SW23 $\left(0.46 \mathrm{~km}^{-1}\right)$, and this suggests that it is less vulnerable to erosion based on the study of the drainage texture.

\section{Analysis of shape morphometric parameters}

The basin shape mainly regulates the rate at which the water is delivered to the secondary channel. These parameters include Elongation ratio (Re), Circulatory ratio (Rc), Form factor (Rf) and Compactness coefficient (Cc). In general, the Re ranges from 0.6 to 1.0 and is correlated with climate and geology (Schumm 1956, Strahler 1964). Re values close to 1.0 are transmitted to very low relief areas, while those values of 0.6-0.8 are correlated with high relief and steep 
slopes on the ground (Dar et al. 2013). The study found that SW12 with the highest Re (0.92) was the least susceptible to erosion and, in comparison, SW22 with the lowest Re (0.41) was the most susceptible to erosion. The Rc is influenced primarily by characteristics such as stream length and frequency, geological structures, climate, relief, and gradient of the basin (Miller 1953). Rc values range from 0 (in line) to 1 (in one circle). In a related study of the SWs of the Shivganga River Basin India by Kadam et al. (2019), a low Rc (i.e. 0.19) indicated rapid discharge from the sub-watershed and consequently, a higher susceptibility to erosion (Kadam et al. 2019). Higher values reflect more basin-shaped circularity and vice-versa. The sub-watershed SW5 in the Imo River Basin with the lowest amount of Rc (0.07) indicates the highest vulnerability to erosion with Rc as the only criterion.

In this way, the Rf has an inverse correlation to erosion; the lowest $\mathrm{Rf}$ values are most susceptible to erosion. The Rf values are within the range of 0.1-0.8 (Horton 1932). High-shaped basins have high peak flows of shorter length whereas elongated drainage basins with low-shaped influences have lower peak flows of longer duration (Singh, Singh 2011, Farhan, Anaba 2016, Asfaw, Workineh. 2019). The results of the Rf derived from the SWs of the Imo River Basin differ from the minimum (0.13) for SW22 up to the maximum (0.66) for SW12. Thus, the Rf analysis places SW22 as being most susceptible to erosion. A watershed's Cc is directly related to the potential for watershed penetration. Therefore, the rating adopted was identical to that adopted by Rf. The lowest Cc was recorded for SW20 with a value of 1.79 , which means that it has the minimum absorption potential and thus the highest erosion sensitivity. The highest was noticed in SW5 with a value of 3.90 implying that it has the highest capacity for infiltration.

\section{Analysis of relief morphometric parameters}

These parameters include Total Basin relief $(\mathrm{H})$, Relief ratio (Rh), and Ruggedness number $(\mathrm{Rn})$. The Total Basin relief $(\mathrm{H})$ is the difference in altitude of the highest and lowest point of a basin valley floor. A strong correlation exists between the hydrological characteristics and a drainage basin's H (Schumm 1956). The H is an indicator of a drainage basin's total slope, as well as the ferocity of the erosion processes functioning on the basin slopes. In this case, the ranking system implemented was equivalent to the one implemented in the case of D, Fs and Rbm, since they all infuse the same erosive traits in any landscape. The lowest basin relief (i.e. 0.57) in a study conducted by Altaf et al. (2014) on the Rembiara Watershed, India was identified in one of the SWs, indicating its low steepness and hence low susceptibility to erosion. Similarly, the lowest value of $\mathrm{H}$ in the Imo River Basin was observed in SW2 $(23 \mathrm{~m})$ which demonstrated its low slope and therefore low risk to erosion. H's highest value was identified in SW24 (308 m), which is due to its high steepness and therefore higher sensitivity to erosion. The next parameter is the Rh that is specifically linked to the slope of the streams and the surface of the earth; which influences the hydrological processes and the watershed's erosion. The Rh basin has a direct correlation with the watershed's erodibility. In the Imo River Basin, the largest rate of Rh was in SW25 (0.020) and its lowest is for SW3 (0.002). Based on this analysis, SW25 is the most vulnerable to erosion compared with other SWs. The final parameter, $\mathrm{Rn}$, is used to compute stream flood potential (Patton, Baker 1976). It symbolises the geometrical characteristics of the sub-basins of the Imo River Basin. Rn has a direct relationship with erodibility so that the erodibility also increases with increasing values of that parameter. The lowest value of Rn was observed for SW2 (0.024) which indicates that it has the lowest susceptibility to erosion. The highest value of $\mathrm{Rn}$ was obtained for SW24 (0.335) which means that it has the greatest susceptibility to erosion. In a study of the Dhidhessa River Basin in Ethiopia by Kabite and Gessesse (2018) the Rn of 3.1 indicated rough topography and susceptibility to soil erosion. Similarly, Kumar and Joshi (2016) derived an $\mathrm{Rn}$ value of 0.78 in another watershed and this was interpreted as having a steep slope and soil erosion susceptibility in the region.

\section{Morphometry analysis-based erodibility prioritisation using WSA approach}

After allocating ranks to the morphometric erosion potential parameters with respect to the relationship with erodibility, the correlation 
matrix was constructed using Pearson's product-moment correlation (r). Several parameters are very highly correlated with each other, and this high level of interdependence is observed between parameters in similar categories (i.e. linear, shape or relief). However, there is a strong negative correlation $(\mathrm{r}=-0.96)$ between two shape parameters, the $\mathrm{Cc}_{\mathrm{c}}$ and Rc, and also a strong positive correlation $(r=0.99)$ between two relief parameters, total basin relief $(\mathrm{H})$ and $\mathrm{Rn}$. The Fw of the parameters were calculated using the WSA approach (Table 6). The correlation matrix showed that the Rbm has a negative correlation with most of the morphometric parameters except the $C_{c}$ which have a positive correlation (0.53). The Re has a strong positive correlation with Rc and Rf and a strong negative correlation with Cc (-0.70). Also, Fs has the highest correlation with drainage texture (0.63).

In the WSA approach, the sum of correlation is the summation of the columns (Table 6) for Dd, Fs, Rbm, Dt, Re, Rc, Rf, Cc, H, Rh, Rn as:

$$
\begin{gathered}
\text { Sum of correlation for } \mathrm{Rn}=[0.38+(-0.29)+ \\
(-0.07)+(-0.07)+(-0.35)+0.05+(-0.34)+ \\
0.00+0.99+0.80+1.00]=2.10
\end{gathered}
$$

Further, the grand total obtained from the sum of correlations (14.71) was used for calculating the final weight of each morphometric parameter using Eq. (1). This was used in the final prioritisation ranking. By assigning those weights to each parameter, a model was formulated to assess the

\begin{tabular}{|c|c|c|c|c|c|c|c|c|c|c|c|}
\hline Parameter & $\mathrm{Dd}$ & Fs & $\mathrm{Rbm}$ & $\mathrm{Dt}$ & $\operatorname{Re}$ & Rc & $\mathrm{Rf}$ & Cc & $\mathrm{H}$ & Rh & $\mathrm{Rn}$ \\
\hline $\mathrm{Dd}$ & 1.00 & $\begin{array}{c}0.16 \\
(0.44)\end{array}$ & $\begin{array}{l}-0.14 \\
(0.51)\end{array}$ & $\begin{array}{c}0.28 \\
(0.17)\end{array}$ & $\begin{array}{l}-0.14 \\
(0.52)\end{array}$ & $\begin{array}{l}-0.05 \\
(0.82)\end{array}$ & $\begin{array}{l}-0.14 \\
(0.51)\end{array}$ & $\begin{array}{c}0.05 \\
(0.80)\end{array}$ & $\begin{array}{c}0.22 \\
(0.29)\end{array}$ & $\begin{array}{c}0.13 \\
(0.55)\end{array}$ & $\begin{array}{c}0.38 \\
(0.06)\end{array}$ \\
\hline Fs & $\begin{array}{c}0.16 \\
(0.44)\end{array}$ & 1.00 & $\begin{array}{l}-0.11 \\
(0.61)\end{array}$ & $\begin{array}{l}0.63^{* *} \\
(0.00)\end{array}$ & $\begin{array}{c}0.35 \\
(0.08) \\
\end{array}$ & $\begin{array}{c}0.04 \\
(0.87) \\
\end{array}$ & $\begin{array}{c}0.39 \\
(0.06) \\
\end{array}$ & $\begin{array}{l}-0.01 \\
(0.98) \\
\end{array}$ & $\begin{array}{l}-0.33 \\
(0.11)\end{array}$ & $\begin{array}{l}-0.20 \\
(0.34)\end{array}$ & $\begin{array}{l}-0.29 \\
(0.15)\end{array}$ \\
\hline $\mathrm{Rbm}$ & $\begin{array}{l}-0.14 \\
(0.51)\end{array}$ & $\begin{array}{l}-0.11 \\
(0.61)\end{array}$ & 1.00 & $\begin{array}{l}-0.22 \\
(0.28)\end{array}$ & $\begin{array}{c}-0.42^{*} \\
(0.04)\end{array}$ & $\begin{array}{c}-0.51^{* *} \\
(0.01)\end{array}$ & $\begin{array}{c}-0.41^{*} \\
(0.04)\end{array}$ & $\begin{array}{l}0.53^{* *} \\
(0.01)\end{array}$ & $\begin{array}{l}-0.04 \\
(0.84)\end{array}$ & $\begin{array}{l}-0.32 \\
(0.12)\end{array}$ & $\begin{array}{l}-0.07 \\
(0.76)\end{array}$ \\
\hline $\mathrm{Dt}$ & $\begin{array}{c}0.28 \\
(0.17)\end{array}$ & $\begin{array}{l}0.63^{* *} \\
(0.00)\end{array}$ & $\begin{array}{l}-0.22 \\
(0.28)\end{array}$ & 1.00 & $\begin{array}{c}0.33 \\
(0.11)\end{array}$ & $\begin{array}{c}0.21 \\
(0.31)\end{array}$ & $\begin{array}{c}0.38 \\
(0.06)\end{array}$ & $\begin{array}{l}-0.08 \\
(0.71)\end{array}$ & $\begin{array}{l}-0.10 \\
(0.63)\end{array}$ & $\begin{array}{l}-0.13 \\
(0.53)\end{array}$ & $\begin{array}{l}-0.07 \\
(0.75)\end{array}$ \\
\hline $\operatorname{Re}$ & $\begin{array}{l}-0.14 \\
(0.52) \\
\end{array}$ & $\begin{array}{c}0.35 \\
(0.08) \\
\end{array}$ & $\begin{array}{c}-0.42^{*} \\
(0.04) \\
\end{array}$ & $\begin{array}{c}0.33 \\
(0.11) \\
\end{array}$ & 1.00 & $\begin{array}{l}0.67^{* *} \\
(0.00) \\
\end{array}$ & $\begin{array}{l}0.99 * * \\
(0.00) \\
\end{array}$ & $\begin{array}{c}-0.70^{* *} \\
(0.00)\end{array}$ & $\begin{array}{l}-0.35 \\
(0.09)\end{array}$ & $\begin{array}{c}0.11 \\
(0.59)\end{array}$ & $\begin{array}{l}-0.35 \\
(0.09)\end{array}$ \\
\hline Rc & $\begin{array}{l}-0.05 \\
(0.82)\end{array}$ & $\begin{array}{c}0.04 \\
(0.87) \\
\end{array}$ & $\begin{array}{c}-0.51^{* *} \\
(0.01)\end{array}$ & $\begin{array}{c}0.21 \\
(0.31)\end{array}$ & $\begin{array}{l}0.67^{* *} \\
(0.00)\end{array}$ & 1.00 & $\begin{array}{l}0.66^{* *} \\
(0.00)\end{array}$ & $\begin{array}{c}-0.96^{* *} \\
(0.00)\end{array}$ & $\begin{array}{c}0.06 \\
(0.79) \\
\end{array}$ & $\begin{array}{l}0.52^{* *} \\
(0.01)\end{array}$ & $\begin{array}{r}0.05 \\
(0.83) \\
\end{array}$ \\
\hline Rf & $\begin{array}{l}-0.14 \\
(0.51)\end{array}$ & $\begin{array}{c}0.39 \\
(0.06) \\
\end{array}$ & $\begin{array}{c}-0.41^{*} \\
(0.04)\end{array}$ & $\begin{array}{c}0.38 \\
(0.06)\end{array}$ & $\begin{array}{l}0.99^{* *} \\
(0.00)\end{array}$ & $\begin{array}{l}0.66^{* *} \\
(0.00)\end{array}$ & 1.00 & $\begin{array}{c}-0.68^{* *} \\
(0.00)\end{array}$ & $\begin{array}{l}-0.33 \\
(0.11)\end{array}$ & $\begin{array}{c}0.10 \\
(0.63)\end{array}$ & $\begin{array}{l}-0.34 \\
(0.10) \\
\end{array}$ \\
\hline Cc & $\begin{array}{c}0.05 \\
(0.80)\end{array}$ & $\begin{array}{l}-0.01 \\
(0.98)\end{array}$ & $\begin{array}{l}0.53^{* *} \\
(0.01)\end{array}$ & $\begin{array}{l}-0.08 \\
(0.71)\end{array}$ & $\begin{array}{c}-0.70^{* *} \\
(0.00)\end{array}$ & $\begin{array}{c}-0.96^{* *} \\
(0.00)\end{array}$ & $\begin{array}{c}-0.68^{* *} \\
(0.00)\end{array}$ & 1.00 & $\begin{array}{l}-0.01 \\
(0.98)\end{array}$ & $\begin{array}{c}-0.51^{*} \\
(0.01)\end{array}$ & $\begin{array}{c}0.00 \\
(0.99)\end{array}$ \\
\hline $\mathrm{H}$ & $\begin{array}{c}0.22 \\
(0.29)\end{array}$ & $\begin{array}{l}-0.33 \\
(0.11)\end{array}$ & $\begin{array}{l}-0.04 \\
(0.84)\end{array}$ & $\begin{array}{l}-0.10 \\
(0.63)\end{array}$ & $\begin{array}{l}-0.35 \\
(0.09)\end{array}$ & $\begin{array}{c}0.06 \\
(0.79)\end{array}$ & $\begin{array}{l}-0.33 \\
(0.11)\end{array}$ & $\begin{array}{l}-0.01 \\
(0.98)\end{array}$ & 1.00 & $\begin{array}{l}0.81^{* *} \\
(0.00)\end{array}$ & $\begin{array}{l}0.99^{* *} \\
(0.00)\end{array}$ \\
\hline $\mathrm{Rh}$ & $\begin{array}{c}0.13 \\
(0.55)\end{array}$ & $\begin{array}{l}-0.20 \\
(0.34)\end{array}$ & $\begin{array}{l}-0.32 \\
(0.12)\end{array}$ & $\begin{array}{l}-0.13 \\
(0.53)\end{array}$ & $\begin{array}{c}0.11 \\
(0.59)\end{array}$ & $\begin{array}{l}0.52^{* *} \\
(0.01)\end{array}$ & $\begin{array}{c}0.10 \\
(0.63)\end{array}$ & $\begin{array}{c}-0.51^{*} \\
(0.01)\end{array}$ & $\begin{array}{l}0.81^{* *} \\
(0.00)\end{array}$ & 1.00 & $\begin{array}{l}0.80^{* *} \\
(0.00)\end{array}$ \\
\hline Rn & $\begin{array}{c}0.38 \\
(0.06)\end{array}$ & $\begin{array}{l}-0.29 \\
(0.15)\end{array}$ & $\begin{array}{l}-0.07 \\
(0.76) \\
\end{array}$ & $\begin{array}{l}-0.07 \\
(0.75) \\
\end{array}$ & $\begin{array}{l}-0.35 \\
(0.09) \\
\end{array}$ & $\begin{array}{c}0.05 \\
(0.83) \\
\end{array}$ & $\begin{array}{l}-0.34 \\
(0.10) \\
\end{array}$ & $\begin{array}{c}0.00 \\
(0.99) \\
\end{array}$ & $\begin{array}{l}0.99 * * \\
(0.00)\end{array}$ & $\begin{array}{l}0.80^{* *} \\
(0.00)\end{array}$ & 1.00 \\
\hline $\begin{array}{l}\text { Sum of } \\
\text { correlation }\end{array}$ & 1.76 & 1.63 & -0.71 & 2.22 & 1.50 & 1.69 & 1.63 & -1.35 & 1.92 & 2.31 & 2.10 \\
\hline $\begin{array}{l}\text { Grand } \\
\text { total }\end{array}$ & 14.71 & 14.71 & 14.71 & 14.71 & 14.71 & 14.71 & 14.71 & 14.71 & 14.71 & 14.71 & 14.71 \\
\hline $\begin{array}{l}\text { Final } \\
\text { weights }\end{array}$ & 0.120 & 0.111 & -0.048 & 0.151 & 0.102 & 0.115 & 0.111 & -0.092 & 0.130 & 0.157 & 0.143 \\
\hline
\end{tabular}
priority. For example, the final weight of $\mathrm{Rn}$ is the

Table 6. Pearson correlation matrix of sub-watershed morphometric parameters.

Significance (2-tailed) are shown in brackets.

** - correlation is significant at the 0.01 level (2-tailed).

* - correlation is significant at the 0.05 level (2-tailed).

Dd - drainage density; Fs - stream frequency; Rbm - mean bifurcation ratio; Dt - drainage texture; Cc - compactness coefficient; Re - elongation ratio; Rc - circulatory ratio; Rf - form factor; $\mathrm{H}$ - total basin relief; $\mathrm{Rh}$ - relief ratio; $\mathrm{Rn}$ ruggedness number. 
sum of correlation i.e. 2.10 divided by the grand total of 14.71 (Table 6). The resulting value (0.143), was used for the calculation of the $\mathrm{Cpc}$, and further used in the SWs' prioritisation and final ranking.

Similarly, the Cpc for SW1 was calculated as follows:

$$
\begin{gathered}
\text { Cpc for SW1 }=(0.120 \times 23)+(0.111 \times 18)+ \\
(-0.048 \times 2)+(0.151 \times 23)+(0.102 \times 14)+ \\
(0.115 \times 5)+(0.111 \times 14)+(-0.092 \times 21)+ \\
(0.130 \times 24)+(0.157 \times 22)+(0.143 \times 24)=19.78
\end{gathered}
$$

In addition, the Cpc values of the $25 \mathrm{SWs}$ in the Imo River Basin were calculated using the WSA method, and prioritization ranking allocation was incorporated as presented in Table 7. The first priority (1) was given to sub-watershed 5 with a Cpc value of 6.25 , with the second priority (2) being sub-watershed 21, with a Cpc value of 7.51. The Imo River Basin's SWs were further classified into four (4) priority groups based on natural breaks (Jenks method) of the Cpc values - very high pri-

\begin{tabular}{|c|c|c|}
\hline $\begin{array}{l}\text { Sub-watershed } \\
\text { ID }\end{array}$ & $\begin{array}{l}\text { Compound param- } \\
\text { eter constant value }\end{array}$ & $\begin{array}{c}\text { WSA final } \\
\text { ranking }\end{array}$ \\
\hline SW1 & 19.78 & 24 \\
\hline SW2 & 21.77 & 25 \\
\hline SW3 & 15.06 & 17 \\
\hline SW4 & 13.25 & 12 \\
\hline SW5 & 6.25 & 1 \\
\hline SW6 & 15.84 & 19 \\
\hline SW7 & 15.89 & 20 \\
\hline SW8 & 14.48 & 15 \\
\hline SW9 & 16.40 & 21 \\
\hline SW10 & 17.56 & 23 \\
\hline SW11 & 14.45 & 14 \\
\hline SW12 & 16.91 & 22 \\
\hline SW13 & 14.90 & 16 \\
\hline SW14 & 9.74 & 7 \\
\hline SW15 & 8.13 & 5 \\
\hline SW16 & 10.50 & 10 \\
\hline SW17 & 13.04 & 11 \\
\hline SW18 & 13.39 & 13 \\
\hline SW19 & 10.10 & 8 \\
\hline SW20 & 15.53 & 18 \\
\hline SW21 & 7.51 & 2 \\
\hline SW22 & 10.24 & 9 \\
\hline SW23 & 8.52 & 6 \\
\hline SW24 & 7.98 & 4 \\
\hline SW25 & 7.80 & 3 \\
\hline
\end{tabular}
ority $(6.25-8.52)$ covering $1035.64 \mathrm{~km}^{2}$ or $41.51 \%$

Table 7. Watershed prioritisation and final ranking for erosion susceptibility. of the basin area $\left(2494.68 \mathrm{~km}^{2}\right)$, high priority (8.52-10.50) covering $262.01 \mathrm{~km}^{2}$ or $10.50 \%$ of the basin area, medium priority (10.50-17.56) covering $1105.82 \mathrm{~km}^{2}$ or $44.33 \%$ of the basin area and low priority (17.56-21.77) covering $91.21 \mathrm{~km}^{2}$ or $3.66 \%$ of the basin area. Of the $25 \mathrm{SWs}$ in the Imo River Basin, 'SW5, SW21, SW25, SW24, SW15, and SW23' fall in very high priority; 'SW14, SW19, SW22, and SW16' fall in high priority; 'SW17, SW4, SW18, SW11, SW8, SW13, SW3, SW20, SW6, SW7, SW9, SW12 and SW10' fall in medium priority; whereas 'SW1 and SW2' fall in the low priority category. The highest priority suggests a greater degree of erosion exists in the sub-watershed and is a potential area for soil conservation measures to be implemented. Figure 5 shows the final erosion susceptibility map of the study area based on the Cpc values.

These results show an improved accuracy in prioritising sub-basins than other methods such as the multi-criteria evaluation approach (Altaf et al. 2014, Alvarado et al. 2016, Vollmer et al. 2016), compound factor analysis (Patel et al. 2012,

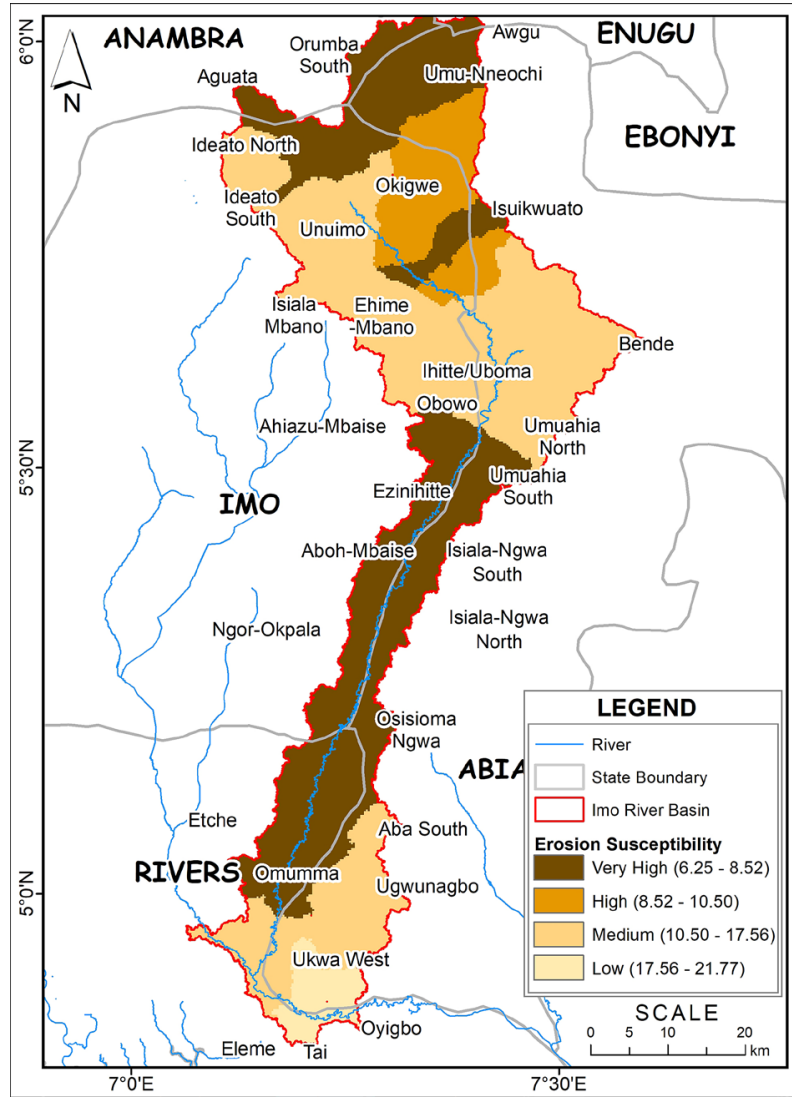

Fig. 5. Erosion susceptibility map of the study area based on $\mathrm{Cpc}$ value. $\mathrm{Cpc}$, compound parameter constant. 
Mohammed et al. 2018) and compound parameter technique (Hlaing et al. 2008, Rawat et al. 2014).

In the past, governmental intervention efforts were initiated in some of these communities to arrest the spate of erosion. For example, gully sites at Umueshi, Amanato and Ntueke in the very high susceptibility area were within the zones marked for rehabilitation by the Imo State Nigeria Erosion and Watershed Management Project (IMO-NEWMAP) in 2014. One of the objectives of IMO-NEWMAP was to reduce the longer-term erosion vulnerability of the communities. In recent media reports on gully erosion in South-East Nigeria, the Isiokpo, Okpulu and Obidioukwu communities of Ideato North Local Government Area (LGA) of Imo State within the very high erosion susceptibility area have received a lot of attention. Residents of these three communities fled their homes on the 1st of September 2018, amid significant gully erosion after heavy rainfall (Channels Television 2018). Chiemelu et al. (2013) also described the Okigwe upland, which falls within the highly susceptible region, as a trouble spot for gully erosion.

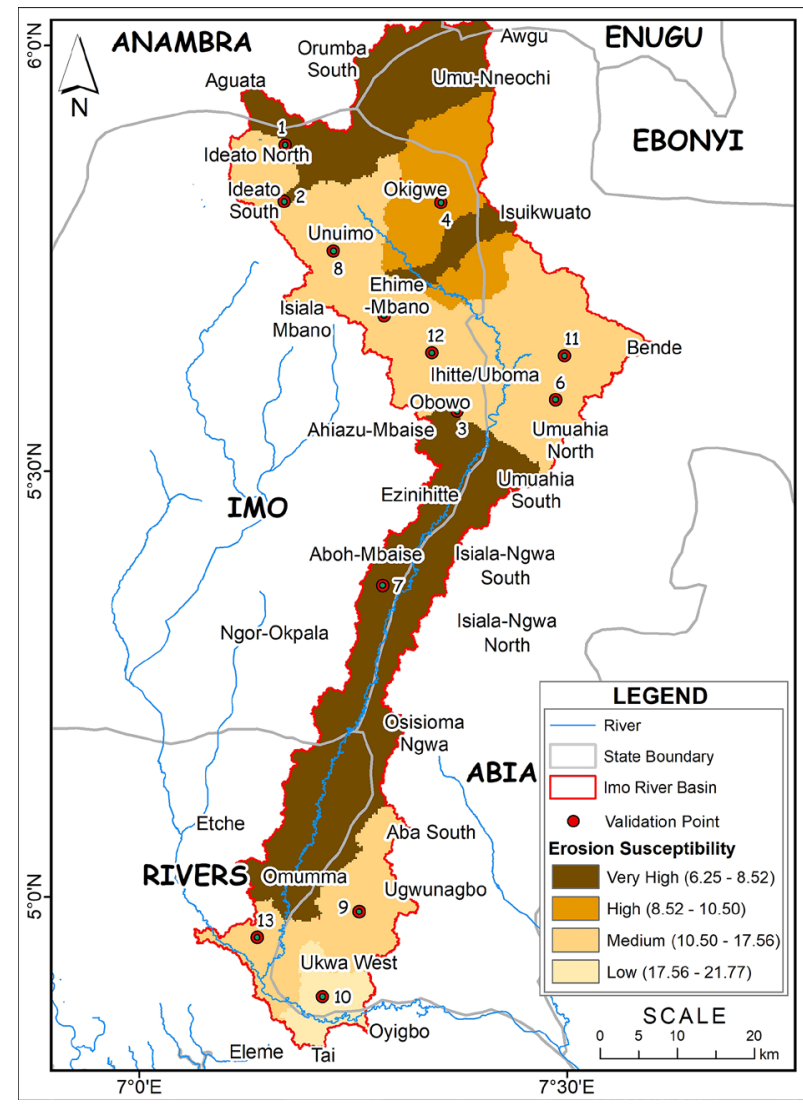

Fig. 6. Overlay of validation points on the erosion susceptibility map.

\section{Model performance evaluation}

The validation points are overlaid on the erosion susceptibility map in Figure 6. The ROC curve plot shown in Figure 7 has the false-positive rate on the $X$-axis and the true-positive rate on the Y-axis. The AUC value computed is 0.810 which implies a prediction accuracy of $81 \%$ of the morphometry-based model.

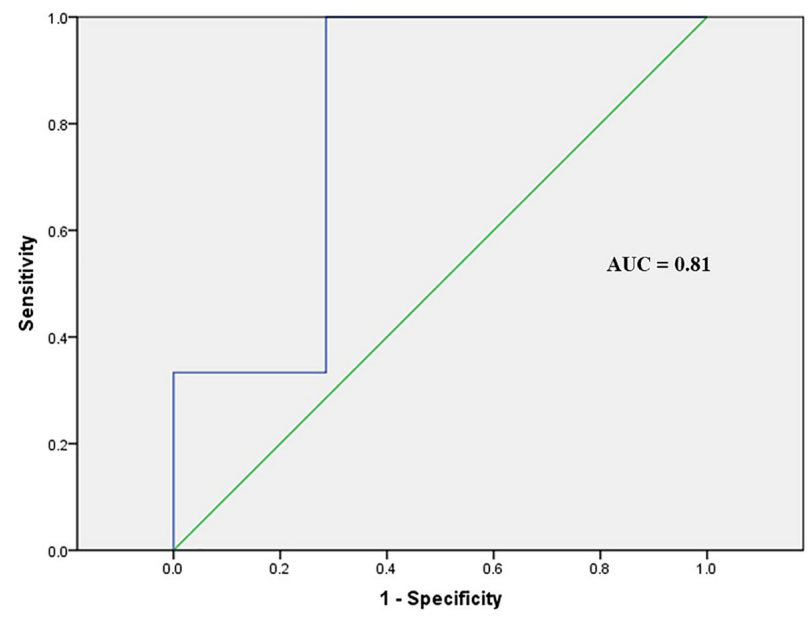

Fig. 7. The ROC technique validation result. ROC, receiver operating characteristics.

\section{Conclusions}

This study successfully classified the Imo River Basin in South-East Nigeria into priority zones based on susceptibility to soil erosion, using a modified geomorphometric prioritisation approach. Soil erosion is a serious environmental problem in the Imo River Basin. Identifying the susceptibility to erosion is a critical measure for ensuring adequate preparedness. This study presents a simple methodology and lowcost strategy for mapping erosion susceptibility on a sub-watershed basis within the Imo River Basin. Several parameters are very highly correlated with each other, and this high level of interdependence is observed between parameters in similar categories (i.e. linear, shape or relief). However, there is a strong negative correlation $(\mathrm{r}=-0.96)$ between two shape parameters, the Cc and Rc. Based on the analysis of linear, shape and relief morphometric parameters, this study has shown the varying levels of erosion susceptibility in the Imo River Basin. For example, in terms of the linear morphometric parameters, the lowest 
volume of Dd which was observed in SW10 indicates a high degree of porosity and a high tendency to resist erosion. Similarly, the high Fs in SW12 which suggests a low soil infiltration puts it at a higher risk of erosion. In terms of the shape parameters, SW22 and SW 5 which had the lowest Re and lowest Rc were also deemed very susceptible to erosion. The minimum absorption potential of SW20 is related to its low Cc, and thus makes it highly susceptible to erosion. Analysis of the relief morphometric parameters showed that SW2 had the lowest total basin relief which implies a low-level relief and low susceptibility to erosion. The Rn which has a relationship with stream flood potential was also computed. SW2 had the lowest Rn thus indicating a low susceptibility to erosion.

The detection of vulnerable areas is a criterion for the design and execution of appropriate soil and water conservation management practices in the Imo River Basin. The results from this study show that $41.51 \%\left(1035.64 \mathrm{~km}^{2}\right)$ of the total area $\left(2494.68 \mathrm{~km}^{2}\right)$ falls under the very-high priority group i.e. areas that are highly susceptible to erosion, $10.50 \%\left(262.01 \mathrm{~km}^{2}\right)$ falls under the high erosion susceptibility class, $44.33 \%\left(1105.82 \mathrm{~km}^{2}\right)$ in the medium susceptibility class and $3.66 \%$ $\left(91.21 \mathrm{~km}^{2}\right)$ in the low erosion susceptibility class. The prediction accuracy of the erosion susceptibility result was determined as $81 \%$ using the ROC curve technique. These SWs need to be taken up immediately by decision-makers and soil and water managers to enforce conservation measures for preventing further erosion.

Soil erosion can be mitigated by adopting sustainable land management practices such as tree planting, zero or reduced tillage, stone bunds, enclosures, terracing and check dams. Also, policy incentives should be provided to encourage the adoption of these practices. This will lead to reduced soil loss and additional household incomes thereby improving livelihoods. Future research priorities should include: sub-surface flow erosion processes, prediction models, application of geographic data and assessment tools in soil erosion control, and issues regarding the adoption of conservation strategies by farmers and individuals. Further research directions include the evaluation of the disparities in the adaptive capacity and resilience of the inhabitants within the river basin to erosion and other ecological disasters. This current study demonstrates that morphometric analysis applied to satellite imagery is a timely and cost-effective approach for providing useful information that can help decision-makers develop more sustainable and environmentally friendly strategies for soil and water conservation.

\section{Acknowledgements}

The authors would like to thank the United States Geological Survey (USGS) for unrestricted access to the SRTM data through the Earth Explorer web portal. The authors also thank the editor and anonymous reviewers of Quaestiones Geographicae for their comments which helped to enhance the quality of the paper.

\section{Conflicts of interest}

The authors declare that they have no conflicts of interest.

\section{Funding}

This study did not receive any financial assistance or grant from the public, private or not-forprofit sectors.

\section{Authors' contribution}

Peter C. Nwilo: project administration, resources, supervision. Caleb O. Ogbeta: conceptualisation, formal analysis, methodology, visualisation, writing - original draft preparation, reviewing and editing. Olagoke E. Daramola: conceptualisation, methodology, validation, visualisation, writing reviewing and editing. Chukwuma J. Okolie: methodology, validation, visualisation, writing - reviewing and editing. Michael J. Orji: visualisation, writing - reviewing and editing.

\section{References}

Adinarayana J., Krishna R.N., Rao K., 1995. An integrated approach for prioritization of watersheds. Journal of Environmental Management 44: 375-384. DOI 10.1016/S03014797(95)90374-7.

Agarwal C.S., 1998. Study of drainage pattern through aerial data in Naugarh area of Varanasi district. U.P. J of Indian Soc of Rem Sensing 26: 169-175. DOI 10.1007/bf02990795.

Akpokodje E.G., Tse A.C., Ekeocha N., 2010. Gully erosion geohazards in Southeastern Nigeria and management implications. Scientia Africana 9(1): 20-36.

Alencar P.H.L., de Araújo J.C., dos Santos Teixeira A., 2020. Physically based model for gully simulation: Application 
to the Brazilian semiarid region. Hydrology and Earth System Sciences 24(8): 4239-4255. DOI 10.5194/hess-24-42392020.

Ali U., Ali S.A., Ikbal J., Bashir M., Fadhi M., Ahmad M., Al Dharab H., Ali S., 2018. Soil erosion risk and flood behavior assessment of Sukhang catchment, Kashmir basin: Using GIS and remote sensing. International Journal of Remote Sensing GIS 7(1): 1-8. DOI 10.4172/24694134.1000230.

Altaf S., Meraj G., Romshoo S.A., 2014. Morphometry and land cover based multi-criteria analysis for assessing the soil erosion susceptibility of the western Himalayan watershed. Environmental Monitoring and Assessment 186(12): 8391-8412. DOI 10.1007/s10661-014-4012-2.

Alvarado A., Esteller M.V., Quentin E., Exposito J.L., 2016. Multi-criteria decision analysis and GIS approach for prioritization of drinking water utilities protection based on their vulnerability to contamination. Water Resource Management 30: 1549-1566. DOI 10.1007/s11269-016-1239-4.

Amangabara G.T., 2015. Drainage morphology of Imo basin in the Anambra-Imo river basin area, of Imo state, southern Nigeria. Journal of Geography, Environment and Earth Science International 3(1): 1-11. DOI 10.9734/jgeesi/2015/17114.

Amangabara G.T., Njoku J.D., Iwuji M.C. 2018. People's perception of soil erosion and its impact in Imo State, Nigeria. IMPACT: International Journal of Research in Applied, Natural and Social Sciences (IMPACT: IJRANSS) ISSN (P): 2347-4580.

Amangabara G.T., Njoku J.D., Obenade M., 2015. Applying satellite remote sensing and GIS tools in the study of gully erosion. Journal of Scientific Research and Reports 4(3): 253-264. DOI 10.9734/jsrr/2015/12753.

Ameri A.A., Pourghasemi H.R., Cerda A., 2018. Erodibility prioritization of sub-watersheds using morphometric parameters analysis and its mapping: A comparison among TOPSIS, VIKOR, SAW, and CF multi-criteria decision-making models. Science of the Total Environment 613-614: 1385-1400. DOI 10.1016/j.scitotenv.2017.09.210.

Anejionu O.C.D., Nwilo P.C., Ebinne E.S., 2013. Long term Assessment and mapping of erosion hotspots in southeastern Nigeria. A paper presented at FIG Working Week 2013 Environment for Sustainability Abuja, Nigeria, 6th-10th May 2013

Arshad M.A., Martin S., 2002. Identifying critical limits for soil quality indicators in agro-ecosystems. Agriculture, Ecosystems \& Environment 88(2): 153-160. DOI 10.1016/ s0167-8809(01)00252-3.

Asfaw D., Workineh G., 2019. Quantitative analysis of morphometry on Ribb and Gumara watersheds: Implications for soil and water conservation. International Soil and Water Conservation Research 7(2): 150-157. DOI 10.1016/j. iswcr.2019.02.003.

Bernard J., Bingner R., Dabney S., Langendoen E., Lemunyon J., Merkel W., Theurer F., Wells R.R., Widman N., Wilson G., 2010. Ephemeral gully erosion - A national resource concern. National Sedimentation Laboratory Technical Research Rep, 69.

Biswas S., Sudhakar S., Desai V.R., 1999. Prioritization of subwatersheds based on morphometric analysis of drainage basin, district Midnapore, West Bengal. Journal of the Indian Society of Remote Sensing 27(3): 155-166. DOI $10.1007 /$ bf02991569.

Borrelli P., Robinson D.A., Fleischer L.R., Lugato E., Ballabio C., Alewell C., Meusburger K., Modugno S., Schütt B.,
Ferro V., Bagarello V., Van Oost K., Montanarella L., Panagos P., 2017. An assessment of the global impact of 21st century land use change on soil erosion. Nature Communications 8(1): 1-13. DOI 10.1038/s41467-017-02142-7.

Borrelli P., Robinson D.A., Panagos P., Lugato E., Yang J.E., Alewell C., Wuepper D., Montanarella L., Ballabio C., 2020. Land use and climate change impacts on global soil erosion by water (2015-2070). Proceedings of the National Academy of Sciences 117(36): 21994-22001. DOI 10.1073/ pnas. 2001403117.

Capra A., Scicolone B., 2002. SW - Soil and water: Ephemeral gully erosion in a wheat-cultivated area in Sicily (Italy). Biosystems Engineering 83: 119-126. DOI 10.1006/ bioe.2002.0092.

Carter J.V., Pan J., Rai S.N., Galandiuk S., 2016. ROC-ing along: Evaluation and interpretation of receiver operating characteristic curves. Surgery 159(6): 1638-1645. DOI 10.1016/j.surg.2015.12.029.

Channels Television, 2018, September 1. Gully Erosion Ravages Three Communities in Imo State [Video file]. Online: youtu.be/18Dfs8vvfao.

Chiemelu N., Okeke F., Nwosu K., Ibe C., Ndukwu R., Ugwuotu A. 2013. The role of surveying and mapping in erosion management and control: A case of Omagba erosion site, Onitsha, Anambra State, Nigeria. Journal of Environment and Earth Sciences 3(11): 11-18.

Chopra R., Dhiman R.D., Sharma P.K., 2005. Morphometric analysis of sub-watersheds in Gurdaspur District, Punjab Using Remote Sensing and GIS Techniques. Journal of the Indian Society of Remote Sensing 33: 531-539. DOI 10.1007/ bf02990738.

Chuenchum P., Xu M., Tang W., 2020. Predicted trends of soil erosion and sediment yield from future land use and climate change scenarios in the Lancang-Mekong River by using the modified RUSLE model. International Soil and Water Conservation Research 8(3): 213-227. DOI 10.1016/j.iswcr.2020.06.006.

Dar R.A., Chandra R., Romshoo S.A., 2013. Morphotectonic and Lithostratigraphic analysis of Intermontane Karewa basin of Kashmir Himalayas, India. Journal of Mountain Science 10(1): 1-15. DOI 10.1007/s11629-013-2494-y.

De Araujo J.C., Güntner A., Bronstert A., 2006. Loss of reservoir volume by sediment deposition and its impact on water availability in semiarid Brazil. Hydrological Sciences Journal 51(1): 157-170. DOI 10.1623/hysj.51.1.157.

Egboka B.C.E., Okpoko E.I., 1984. Gully erosion in the Agulu-Nanka region of Anambra State, Nigera. Challenges in African Hydrology and Water Resources (Proceedings of the Harare Symposium). IAHS Publ. No. 144.

Ezezika O.C., Adetona O., 2011. Resolving the gully erosion problem in Southeastern Nigeria: Innovation through public awareness and community-based approaches. Journal of Soil Science and Environmental Management 2(10): 286-291.

Farhan Y., Anaba O., 2016. Watershed prioritization based on morphometric analysis and soil loss modeling in Wadi Kerak (Southern Jordan) using GIS techniques. International Journal of Plant and Soil Science 10: 1-18. DOI 10.9734/ijpss/2016/25321.

Farhan Y., Anbar A., Al-Shaikh N., Mousa R., 2017. Prioritization of semi-arid agricultural watershed using morphometric and principal component analysis, remote sensing, and GIS techniques, the Zerqa River Watershed, Northern Jordan. Agricultural Sciences 8(1): 113-148. DOI 10.4236/as.2017.81009. 
Farr T.G., Rosen P.A., Caro E., Crippen R., Duren R., Hensley S., Kobrick M., Paller M., Rodriguez E., Roth L., Seal D., Shaffer S., Shimada J., Umland J., Werner M., Oskin M., Burbank D., Alsdorf D., 2007. The shuttle radar topography mission-RG2004. Reviews of Geophysics 45(2): 1-33. DOI 10.1029/2005rg000183.

Fayas C.M., Abeysingha N.S., Nirmanee K.G.S., Samaratunga D., Mallawatantri A. 2019. Soil loss estimation using rusle model to prioritize erosion control in KELANI river basin in Sri Lanka. International Soil and Water Conservation Research 7(2): 130-137. DOI 10.1016/j.iswcr.2019.01.003.

Forkuor G., Maathuis B., 2012. Comparison of SRTM and ASTER derived digital elevation models over two regions in Ghana - Implications for Hydrological and Environmental Modeling. Studies on Environmental and Applied Geomorphology. DOI 10.5772/28951.

Gajbhiye S., Mishra S.K., Pandey A., 2014. Prioritizing erosion-prone area through morphometric analysis: An RS and GIS perspective. Applied Water Science 4(1): 51-61. DOI 10.1007/s13201-013-0129-7.

Gao P., 2013. Rill and gully development processes. In: Shroder, J. (Editor in Chief), Marston, R.A., Stoffel, M. (eds.), Treatise on geomorphology. Vol. 7, Mountain and Hillslope Geomorphology, Academic Press, San Diego, CA: 122 131. DOI 10.1016/B978-0-12-374739-6.00156-1.

Harlin J.M., Wijeyawickrema C., 1985. Irrigation and groundwater depletion in Caddo county, Oklahoma. JAWRA Journal of the American Water Resources Association 21(1): 15-22. DOI 10.1111/j.1752-1688.1985.tb05346.x.

Hlaing K.T., Haruyama S., Aye M.M., 2008. Using GIS-based distributed soil loss modeling and morphometric analysis to prioritize watershed for soil conservation in Bago river basin of Lower Myanmar. Frontiers of Earth Science China. 2(4): 465-478. DOI 10.1007/s11707-008-0048-3.

Horton R.E., 1932. Drainage basin characteristics. Transactions of the American Geophysical Union 13: 350-361. DOI 10.1029/tr013i001p00350.

Horton R.E., 1940. An approach toward a physical interpretation of infiltration capacity. Proc. Soil Sci. Soc. Amer. 5: 399-417. DOI 10.2136/sssaj1941.036159950005000C0075x.

Horton R.E., 1945. Erosional development of streams and their drainage basins: Hydrophysical approach to quantitative morphology. Geological Society of America Bulletin 56: 275-370. DOI 10.1130/0016-7606(1945)56[275:EDOSAT]2.0.CO;2.

Howard A.D., 1990. Role of hypsometry and planform in basin hydrologic response. Hydrological Processes 4(4): 373-385. DOI 10.1002/hyp.3360040407.

Jang T., Vellidis G., Hyman J.B., Brooks E., Kurkalova L.A., Boll J., Cho J., 2013. Model for prioritizing best management practice implementation: Sediment load reduction. Environmental Management 51: 209-224. DOI 10.1007/ s00267-012-9977-4.

Javed A., Khanday M.Y., Ahmed R., 2009. Prioritization of sub-watersheds based on morphometric and land use analysis using remote sensing and GIS techniques. Journal of the Indian society of Remote Sensing 37(2): 261. DOI 10.1007/s12524-009-0016-8.

Jawaharraj N., Kumaraswami K., Ponnaiyan K., 1998. Morphometric analysis of the Upper Noyil basin (Tamil Nadu). Journal of the Deccan Geographical Society 36: 1529.

Kabite G., Gessesse B., 2018. Hydro-geomorphological characterization of Dhidhessa River basin, Ethiopia. International Soil and Water Conservation Research 6(2): 175-183. DOI 10.1016/j.iswcr.2018.02.003.
Kadam A.K., Jaweed T.H., Kale S.S., Umrikar B.N., Sankhua R.N., 2019. Identification of erosion-prone areas using modified morphometric prioritization method and sediment production rate: A remote sensing and GIS approach. Geomatics, Natural Hazards and Risk 10(1): 9861006. DOI 10.1080/19475705.2018.1555189.

Kumar P., Joshi V., 2016. Characterization of hydro geological behavior of the upper watershed of River Subarnarekha through Morphometric analysis using Remote Sensing and GIS approach. International Journal of Environmental Sciences 6(4): 429-447.

Kumaraswami K., Sivagnanam N., 1998. Morphometric charecteristics of the vaippar Basin, Tamil Nadu: A qualitative approach. Indian Journal of landscape System and Ecological Studies 11(11): 94101.

Lal R., 2003. Soil erosion and the global carbon budget. Environment international 29(4): 437-450. DOI 10.1016/S01604120(02)00192-7.

Liu X.-l., Tang C., Ni H.-Y., Zhao Y., 2016. Geomorphologic analysis and physico-dynamic characteristics of Zhatai-Gully debris flows in SW China. Journal of Mountain Science 13(1): 137-145. DOI 10.1007/s11629-0143267-y.

Macka Z., 2001. Determination of texture of topography from large scale contour maps. Geografski Vestnik 73(2): 53-62.

Maidment D.R., 2002. ArcHydro GIS for water resources. Esri Press, California.

Miller V.C., 1953. A quantitative geomorphic study of drainage basin characteristics in the Clinch Mountain area, Virginia and Tennessee, Technical Report 3 NR 389-402, Columbia University, Department of Geology, ONR, New York, NY, USA.

Mohammed A., Adugna T., Takala W., 2018. Morphometric analysis and prioritization of watersheds for soil erosion management in Upper Gibe catchment. Journal of Degraded and Mining Lands Management 6(1): 1419-1426. DOI 10.15243/jdmlm.2018.061.1419.

Montanarella L., Pennock D., McKenzie N., Badraoui M., Chude V., Baptista I., Mamo T., Yemefack M., Aulakh M.S., Yagi K., Hong S.Y., Vijarnsorn P., Zhang G.-L., Arrouays D., Black H., Krasilnikov P., Sobocká J., Alegre J., Henriquez C.R., Mendonça-Santos M. de L., Taboada M., Espinosa-Victoria D., AlShankiti A., AlaviPanah S.K., Elsheikh E.A.El M., Hempel J., Arbestain M.C., Nachtergaele F., Vargas R., 2016. World's soils are under threat. Soil 2: 79-82. DOI 10.5194/soil-2-79-2016.

Montgomery D.R., Dietrich W.E., 1992. Channel initiation and the problem of landscape scale. Science 255: 826-830. DOI 10.1126/science.255.5046.826.

Nag S., Chakraborty S., 2003. Influence of rock types and structures in the development of drainage network in hard rock area. Journal of the Indian Society of Remote Sensing 31(1): 25-35. DOI 10.1007/BF03030749.

NASA JPL, 2014. U.S. Releases Enhanced Shuttle Land Elevation Data. NASA Jet Propulsion Laboratory (JPL). http:/ / www.jpl.nasa.gov $/$ news $/$ news.php? release $=2014-321$ (accessed 21 December 2020).

Nautiyal M.D., 1994. Morphometric analysis of drainage basin, district Dehradun, Uttar Pradesh. Journal of Indian Society of Remote Sensing. 22(4): 252-262. DOI 10.1007/ BF03026526.

Nelson H.D., Huffman L.H., Fu R., Harris E.L., 2005. Force USPST. Genetic risk assessment and BRCA mutation testing for breast and ovarian cancer susceptibility: Systematic evidence review for the U.S. Preventive Services 
Task Force. Annals of Internal Medicine 143: 362-79. DOI 10.7326/0003-4819-143-5-200509060-00012.

Nigeria - Erosion and Watershed Management Project, 2012. World Bank Group, Washington, D.C. Online: documents. worldbank.org/curated/en/728741468334143813/Nigeria-Erosion-and-Watershed-Management-Project. documents.worldbank.org/en/publication/documents-reports/documentdetail/728741468334143813/ nigeria-erosion-and-watershed-management-project (accessed 13 May 2021).

NIMET [Nigeria Meteorological Agency], 2019. Seasonal Rainfall Prediction (SRP). Periodic Monitoring Report, Saturday, 2 February, 2019. nimet.gov.ng fscluster.org/nigeria/document/nigerian-meteorological-agency-nimet dropbox.com/s/ojqlmvczw8barc6/NIMET\%20SRP\%20 COMPLETE.pdf?dl=0; (accessed 18 December 2019)

Nkonya E., Anderson W., Kato E., Koo J., Mirzabaev A., von Braun J., Meyer S., 2016. Global cost of land degradation economics of land degradation and improvement - A global assessment for sustainable development. Springer, Cham: 117-165. DOI 10.1007/978-3-319-19168-3_6.

Nwilo P.C., Olayinka D.N., Uwadiegwu I., Adzandeh A.E., 2011. An assessment and mapping of gully erosion hazards in Abia State: A GIS approach. Journal of Sustainable Development 4(5): 196. DOI 10.5539/jsd.v4n5p196.

Obiadi I.I., Nwosu C.M., Ajaegwu N.E., Anakwuba E.K., Onuigbo N.E., Akpunonu E.O., Ezim O.E. 2011. Gully Erosion in Anambra State, South East Nigeria: Issues and solution. International Journal of Environmental Sciences 2(2): 795-804.

Ofomata G.E.K., 1965. Factors of soil erosion in the Enugu area of Nigeria. The Nigerian Geographic Journal 8(1): 45-59.

Ogbukagu I.K.N., 1976. Soil erosion in the northern parts of the Awka-Orlu Uplands, Nigeria. Nigerian Journal. Mining \& Geology 13: 6-19.

Okagbue C.O., Uma K.O., 1987. Performance of gully erosion control measures in southeastern Nigeria. Forest Hydrology and Watershed Management (Proceedings of the Vancouver Symposium), Actes du Co11oque de Vancouver, Publ. No. 167.

Okali D., Okpara E., Olawoye J., 2001. The case of Aba and its region, southeastern Nigeria. International Institute for Environment and Development 4: 12-20.

Okereke C.N., Onu N.N., 2012. Mapping gully erosion using remote sensing technique: A case study of Okigwe Area, Southeastern Nigeria. International Journal of Engineering Research and Applications 2(3): 1955-1967.

Panagos P., Borrelli P., Robinson D., 2019. FAO calls for actions to reduce global soil erosion. Mitigation and $\mathrm{Ad}-$ aptation Strategies for Global Change, 25(5): 789-790. DOI 10.1007/s11027-019-09892-3.

Patel A., Katiyar S., Prasad V., 2016. Performances evaluation of different open source DEM using Differential Global Positioning System (DGPS). The Egyptian Journal of Remote Sensing and Space Science 19(1): 7-16. DOI 10.1016/j. ejrs.2015.12.004.

Patel D., Gajjar C., Srivastava P., 2013. Prioritization of Malesari mini-watersheds through morphometric analysis: A remote sensing and GIS perspective. Environmental Earth Sciences. 69: 2643-2656. DOI 10.1007/s12665-012-2086-0.

Patel D.P., Dholakia M.B., Naresh N., Srivastava P.K., 2012. Water harvesting structure positioning by using geo-visualization concept and prioritization of Mini-Watersheds through morphometric analysis in the lower Tapi Basin. Journal of the Indian Society of Remote Sensing 40(2): 299_ 312. DOI 10.1007/s12524-011-0147-6.
Patton P.C., Baker V.R., 1976. Morphometry and floods in small drainage basins subject to diverse hydrogeomorphic controls. Water Resources Research 12(5): 941-952. DOI 10.1029/WR012i005p00941.

Pinheiro E.A.R., Metselaar K., de Jong van Lier Q., de Araújo J.C., 2016. Importance of soil-water to the Caatinga biome, Brazil. Ecohydrology 9(7): 1313-1327. DOI 10.1002/ eco.1728.

Poesen J., 2018. Soil erosion in the Anthropocene: Research needs. Earth Surface Processes and Landforms 43(1): 64-84. DOI 10.1002/ esp.4250.

Poesen J., Nachtergaele J., Verstraeten G., Valentin C., 2003. Gully erosion and environmental change: Importance and research needs. Catena 50(2-4): 91-133. DOI 10.1016/ S0341-8162(02)00143-1.

Pontius R.G., Schneider L.C., 2001. Land-cover change model validation by an ROC method for the Ipswich watershed, Massachusetts, USA. Agriculture, Ecosystems $\mathcal{E}$ Environment 85(1-3): 239-248. DOI 10.1016/S01678809(01)00187-6.

Prasad R., Mondal N., Banerjee P., Nandakumar M., Singh V., 2008. Deciphering potential groundwater zone in hard rock through the application of GIS. Environmental Geology 55(3): 467-475. DOI 10.1007/s00254-007-0992-3.

Rahaman S.A., Ajeez S.A., Aruchamy S., Jegankumar R., 2015. Prioritization of sub watershed based on morphometric characteristics using fuzzy analytical hierarchy process and geographical information system - A study of Kallar Watershed, Tamil Nadu. Aquatic Procedia 4: 1322-1330. DOI 10.1016/j.aqpro.2015.02.172.

Ratnam K.N., Srivastava Y., Rao V.V., Amminedu E., Murthy K., 2005. Check dam positioning by prioritization of micro-watersheds using SYI model and morphometric analysis - remote sensing and GIS perspective. Journal of the Indian Society of Remote Sensing 33(1): 25. DOI 10.1007/ BF02989988.

Rawat K.S., Tripathi V.K., Mishra A.K., 2014. Sediment yield index mapping and prioritization of Madia subwatershed, Sagar District of Madhya Pradesh (India). Arabian Journal of Geosciences 7(8): 3131-3145. DOI 10.1007/ s12517-013-1007-1.

Sartori M., Philippidis G., Ferrari E., Borrelli P., Lugato E., Montanarella L., Panagos P., 2019. A linkage between the biophysical and the economic: Assessing the global market impacts of soil erosion. Land Use Policy 86: 299-312. DOI 10.1016/j.landusepol.2019.05.014.

Schumm S.A. 1956. Evolution of drainage systems and slopes in badlands at Perth Amboy, New Jersey. Bulletin of the Geological Society of America 67: 597-646. DOI 10.1130/0016-7606(1956)67[597:EODSAS]2.0.CO;2.

Singh V., Singh U., 2011. Basin Morphometry of Maingra River, district Gwalior, Madhya Pradesh, India. International journal of Geomatics and Geosciences 1(4): 891-902.

Sreedevi P.D., Srinivasalu S., Kesava Raju K., 2001. Hydrogeomorphological and groundwater prospects of the Pageru River basin by using remote sensing data. Environmental Geology 40(8): 1088-1094. DOI 10.1007/ s002540100295.

Srivastava V.K., 2003. Role of GIS in natural resources management. In: Thakur B. (ed.), Perspectives in resource management in developing countries. Concept Publishing Company, New Delhi: 479-484.

Strahler A.N., 1950. Equilibrium theory of erosional slopes approached by frequency distribution analysis; Part II. American Journal of Science, 248(11): 800-814. DOI 10.2475/ajs.248.11.800. 
Strahler A.N., 1957. Quantitative analysis of watershed geomorphology. Transactions of the American Geophysical Union 38: 913-920. DOI 10.1029/TR038i006p00913.

Strahler A.N., 1964. Quantitative geomorphology of drainage basins and channel networks. In: Chow V.T. (ed.), Handbook of applied hydrology. McGraw Hill Book Company, New York: 4-11.

Strahler A.N., 1968. Quantitative Geomorphology. In Faibridge, R.W (ed.), The Encyclopedia of Geomorphology, Reinhold Book Crop., New York: 898-912. DOI 10.1007/3-54031060-6_304.

Sun G., Ranson K.J., Kharuk V.I., Kovacs K., 2003. Validation of surface height from shuttle radar topography mission using shuttle laser altimeter. Remote Sensing of Environment 88(4): 401-411. DOI 10.1016/j.rse.2003.09.001.

Vaidya N., Kuniyal J.C., Chauhan R., 2013. Morphometric analysis using Geographic Information System (GIS) for sustainable development of hydropower projects in the lower Satluj river catchment in Himachal Pradesh, India. International journal of Geomatics and Geosciences 3(3): 464-473.

Valentin C., Poesen J., Li Y., 2005. Gully erosion: Impacts, factors and control. Catena 63(2-3): 132-153. DOI 10.1016/j catena.2005.06.001.

Vanmaercke M., Poesen J., Van Mele B., Demuzere M., Bruynseels A., Golosov V., Bezerra J.F.R., Bolysov S., Dvinskih A., Franki A., Fuseina Y., Guerra A.J.T., Haregeweyn N., Ionita I., Imwangana F.M., Moeyersons J., Moshe I., Sam- ani A.Z., Niacșu L., Rysin I., Ryzhov Yu.V., Yermolaev O.P., Frankl A., 2016. How fast do gully headcuts retreat? Earth-Science Reviews 154: 336-355. DOI 10.1016/j.earscirev.2016.01.009.

Verstraeten G., Bazzoffi P., Lajczak A., Rãdoane M., Rey F., Poesen J., de Vente J., 2006. Reservoir and pond sedimentation in Europe. Soil Erosion in Europe 759-774. DOI 10.1002/0470859202.ch54.

Vollmer D., Pribadi D.O., Remondi F., Rustiadi E., Grêt-Regamey A., 2016. Prioritizing ecosystem services in rapidly urbanizing river basins: A spatial multi-criteria analytic approach. Sustainable Cities and Society 20: 237-252. DOI 10.1016/j.scs.2015.10.004.

Wei R., Zeng Q., Davies T., Yuan G., Wang K., Xue X., Yin Q., 2018. Geohazard cascade and mechanism of large debris flows in Tianmo gully, SE Tibetan Plateau and implications to hazard monitoring. Engineering Geology 233: 172-182. DOI 10.1016/j.enggeo.2017.12.013.

Yibeltal M., Tsunekawa A., Haregeweyn N., Adgo E., Meshesha D.T., Aklog D., Masunaga T., Tsubo M., Billi P., Vanmaercke M., Ebabu K., Dessie M., Sultan D., Liyew M., 2019. Analysis of long-term gully dynamics in different agro-ecology settings. Catena 179: 160-174. DOI 10.1016/j.catena.2019.04.013.

Zhang X., Li X., Feng Y., Liu Z., 2015. The use of ROC and AUC in the validation of objective image fusion evaluation metrics. Signal Processing 115: 38-48. DOI 10.1016/j. sigpro.2015.03.007. 